\title{
RNA-Binding Proteins as Regulators of Migration, Invasion and Metastasis in Oral Squamous Cell Carcinoma
}

\author{
Jonas Weiße ${ }^{1, \dagger}$, Julia Rosemann ${ }^{1, \dagger}$, Vanessa Krauspe ${ }^{1}$, Matthias Kappler ${ }^{2}{ }^{\circledR}$, \\ Alexander W. Eckert ${ }^{3}$, Monika Haemmerle ${ }^{4}$ (D) and Tony Gutschner ${ }^{1, *(D)}$ \\ 1 Junior Research Group 'RNA Biology and Pathogenesis', Medical Faculty, Martin-Luther University \\ Halle-Wittenberg, 06120 Halle/Saale, Germany; jonas.weisse@uk-halle.de (J.W.); \\ julia.rosemann@uk-halle.de (J.R.); vanessa.krauspe@student.uni-halle.de (V.K.) \\ 2 Department of Oral and Maxillofacial Plastic Surgery, Medical Faculty, Martin Luther University \\ Halle-Wittenberg, 06120 Halle (Saale), Germany; matthias.kappler@uk-halle.de \\ 3 Department of Cranio Maxillofacial Surgery, Paracelsus Medical University, 90471 Nuremberg, Germany; \\ alexander.eckert@klinikum-nuernberg.de \\ 4 Institute of Pathology, Section for Experimental Pathology, Medical Faculty, Martin-Luther University \\ Halle-Wittenberg, 06120 Halle/Saale, Germany; monika.haemmerle@uk-halle.de \\ * Correspondence: tony.gutschner@uk-halle.de; Tel.: +49-345-557-3945 \\ + These authors contributed equally to this work.
}

Received: 26 August 2020; Accepted: 17 September 2020; Published: 17 September 2020

\begin{abstract}
Nearly 7.5\% of all human protein-coding genes have been assigned to the class of RNA-binding proteins (RBPs), and over the past decade, RBPs have been increasingly recognized as important regulators of molecular and cellular homeostasis. RBPs regulate the post-transcriptional processing of their target RNAs, i.e., alternative splicing, polyadenylation, stability and turnover, localization, or translation as well as editing and chemical modification, thereby tuning gene expression programs of diverse cellular processes such as cell survival and malignant spread. Importantly, metastases are the major cause of cancer-associated deaths in general, and particularly in oral cancers, which account for $2 \%$ of the global cancer mortality. However, the roles and architecture of RBPs and RBP-controlled expression networks during the diverse steps of the metastatic cascade are only incompletely understood. In this review, we will offer a brief overview about RBPs and their general contribution to post-transcriptional regulation of gene expression. Subsequently, we will highlight selected examples of RBPs that have been shown to play a role in oral cancer cell migration, invasion, and metastasis. Last but not least, we will present targeting strategies that have been developed to interfere with the function of some of these RBPs.
\end{abstract}

Keywords: HNSCC; oral cancer; OSCC; RBP; IGF2BP3; LIN28; HuR; METTL3; DDX3

\section{Introduction}

Cancers of the lip, tongue and oral cavity were estimated to collectively account for approximately 355,000 newly diagnosed neoplasia and over 177,000 cancer deaths in 2018 ranking oral cancer on position 16 and 15 in terms of incidence and mortality, respectively [1,2]. Oral squamous cell carcinoma (OSCC), which account for more than $90 \%$ of all oral tumors develop from cells in the basal layer of the oral epithelium and originate from either altered stem cells or through dedifferentiation of early-stage differentiated cells [3-5]. Known risk factors of oral cancer include tobacco and alcohol abuse, consumption of areca nut products as well as human papilloma virus (HPV) infection [6-8]. Carcinogen exposure can trigger a complex multistep process characterized by an accumulation 
of genetic and epigenetic alterations that lead to genomic instability and loss of tumor suppressor genes (TP53, CDKN2A, RB1, RBL1/2) as well as activation of oncogenic signaling pathways including epithelial growth factor receptor (EGFR), phosphatidylinositol-3-kinase (PI3K)/AKT/mammalian target of rapamycin (mTOR), mitogen-activated protein kinase (MAPK), and Janus kinase/signal transducers and activators of transcription (JAK/STAT) that contribute to oral cancer progression $[9,10]$. In HPV-negative patients, more than $80 \%$ of the tumors harbor TP53 loss-of-function mutations, which occur in early stages often combined with mutations in the Rb pathway [11,12]. In HPV-positive patients, p53 protein is degraded via HPV E6 and pRb via HPV E7. In addition, a high prevalence of inactivating mutations in NOTCH1 have been identified suggesting a tumor-suppressive role of Notch signaling in head and neck squamous cell carcinomas (HNSCC) in general and OSCC in particular [11]. However, several lines of evidence are emerging and support the idea of a rather oncogenic function of the Notch1 pathway which might be an attractive target for treatment of HNSCC [13,14].

Identification of novel and high-confidence therapeutic targets in OSCC is an urgent need and despite significant advances in the diagnosis and treatment, the 5-year survival rate is $\sim 60 \%$, which decreases to $\sim 30 \%$ for patients with advanced disease (https://seer.cancer.gov/csr/1975_2006/) [15,16]. One reason for this high mortality rate is the late diagnosis of OSCC when the cancer has already metastasized. In fact, at the time of diagnosis, over $50 \%$ of oral cancer patients in the United States have already developed regional or distant disease [17]. Moreover, OSCC has a high recurrence rate and frequently metastasizes to cervical lymph nodes with lymph node metastasis occurring in $40 \%$ of OSCC patients [18-20]. Lymph node involvement and extracapsular spread are strong prognostic factors [21,22]. The overall prevalence of distant metastasis in clinical studies commonly lies between 8-14\% [18]. In contrast, autopsy studies revealed a $40-57 \%$ incidence of patients with distant metastasis [23-25]. The lung is the most frequent site for OSCC metastasis $(\sim 80 \%)$ followed by bone, liver and mediastinal nodes [18,24]. Once distant metastases are diagnosed, the median time to death is only 3.3 months [18]. Thus, understanding the mechanisms responsible for the malignant spread of oral cancer cell is key to develop effective therapeutics and extend the life of patients.

The development of metastasis is a multifactorial phenomenon, which, in the case of head and neck cancers, includes the following factors that significantly increase distant metastasis: extracapsular extension, location of the primary tumor in the hypopharynx, higher stage grouping, $\mathrm{N}$ classification, locoregional failure, including relapse and persistent disease [18]. HPV positivity was associated with less distant metastasis [18]. In addition, lymphovascular and perineural invasion have been suggested to affect distant metastasis and survival by some studies, yet their role in oral cancer remains controversial [18,26-29]. Importantly, our current understanding of the underlying molecular events and individual factors involved in the metastatic dissemination of oral cancer cells is still very limited. It is well-known that several steps along the invasion-metastasis cascade have to be taken by tumor cells in order to spread from the primary tumor site to an anatomically distant location [30]. First, the cells have to detach from the primary tumor and locally breach the basement membrane in order to invade the surrounding extracellular matrix and connective tissue. Next, the cancer cells have to intravasate the blood or lymphatic vessels and travel to distant anatomical sites where they extravasate from the vessels into the stroma of the metastatic site. Here, the tumor cells form micrometastases and eventually begin to expand and start their proliferative program to colonize the tissue and ultimately form macrometastases. Importantly, in order to be successful, tumor cells need to be able to tolerate and adapt to several different stress factors and changing environments. Hence, it is increasingly recognized that phenotypic plasticity, largely driven by epigenetic and transcriptional mechanisms, markedly influences the metastatic progression [31-33]. A well-studied and important source of plasticity of malignancy is epithelial- to-mesenchymal transition (EMT), an epigenetically controlled event that enables transitions of malignant cells between different phenotypic states that confer motility and enhance survival [5]. During EMT of cancer cells, which is promoted by an inflammatory immune response and the hypoxic microenvironment, cells lose their adhesiveness and apical-basal polarity, and undergo both cytoskeletal and signaling changes which enhances their ability 
to migrate and invade $[5,34,35]$. EMT and its underlying regulatory mechanisms have been extensively studied and a central role for EMT in the metastasis of several cancer types, including OSCC has been described [36,37]. However, some controversies regarding the contribution and significance of EMT to tumor progression exist and alternative mechanisms of migration have to be considered, also in combination, to capture the full spectrum of cell states, which is a prerequisite to develop effective anti-metastasis strategies [38-40].

Of note, cellular plasticity conferred by EMT and other mechanisms that lead to morphological and functional changes requires robust reprogramming of gene expression programs. For example, several thousand genes change their expression in a context-dependent manner during EMT [41]. These profound changes require multiple layers of regulation, from transcription, to post-transcriptional RNA processing, to translational and post-translational modifications. While transcriptional regulation by EMT-associated transcription factors, e.g., members of the zinc finger E-box binding homeobox (ZEB), SNAIL and TWIST families, is generally considered the most important mode of regulation, mounting evidence indicates that post-transcriptional events strongly contribute to the fine-tuning of EMT [42-44]. This fine-tuning can be achieved through the action of microRNAs (miRNAs) and long non-coding RNAs (lncRNAs) as well as RNA-binding proteins (RBPs) [45-50].

In this review, we will focus on RNA-binding proteins and we will offer a brief overview about their general contribution to post-transcriptional regulation of gene expression. Subsequently, we will highlight selected examples of RBPs that have been shown to play a role in oral cancer cell migration, invasion, and metastasis. Last but not least, we will present targeting strategies that have been developed to interfere with the function of some of these RBPs.

\section{General Functions and Mechanisms of RNA-Binding Proteins}

Over the past decade, RBPs have been increasingly recognized as important regulators of molecular and cellular homeostasis. RBPs regulate diverse cellular processes such as cell survival, pluripotency of embryonic stem cells, and immune cell function, as well as aid in the transition between cellular states in response to stimuli, e.g., during differentiation, cellular stress, or viral infection [51-58]. Nearly $7.5 \%$ of all human protein-coding genes have been assigned to the class of RBPs (1542). These annotations were initially based upon the presence of characteristic RNA binding domains as well as their association with polyadenylated RNA-containing protein complexes that have been purified using a poly(A)-capture strategy [59-62]. An updated annotation compiled a list of 1914 and 1393 RBPs expressed in human and murine cells [63]. In addition, a recently developed experimental strategy to explore the complete RNA-bound proteome identified 1207, 1239, and 1357 proteins in MCF7, HeLa and HEK293 cells, respectively. 858 proteins were shared by all three cell lines. This study finally arrived at an integrated human RNA-binding proteome comprised of 978 proteins $(70 \%)$ of previous poly(A) interactomes and 775 proteins constituting a novel non-poly(A) interactome [64].

In order to fulfill their cellular tasks and to influence the fate of hundreds to thousands of transcripts RBPs interact with specific sequences or RNA secondary structure elements within their respective target RNA to regulate its post-transcriptional processing, i.e., its alternative splicing, polyadenylation, stability and turnover, localization, or translation as well as editing and chemical modification. Therefore, RBPs typically contain discrete domains for the purpose of binding RNA and more than 40 RNA-binding domains (RBDs) have been described [59]. Importantly, RBDs are quite small (less than 100 amino acids) and utilize only a fraction of their residues to directly interact with RNA via hydrogen bonds, stacking interactions, and other weaker interactions. To achieve specificity multiple binding domains often co-exist within one RBP, thereby enhancing specific RNA binding [65]. Furthermore, linkers or intrinsically disordered regions between individual domains have been shown to mediate important RNA contacts as well, and the flexibility of linkers can determine whether adjacent RNA-binding domains bind independently or cooperatively [66]. Intriguingly, many of the recently identified RBPs, including a large group of metabolic enzymes, lack conventional RBDs and have no established connection to RNA processing events [67]. Hence, the exact nature and functional 
consequences of many of these RNA-protein interactions remain largely unknown. Nevertheless, an analysis of the genomic distribution of RBP binding motifs within their target transcripts revealed a large proportion of these motifs to be localized within the non-coding parts of the human genome, especially within introns and 3' untranslated regions (UTRs) of messenger RNAs (mRNAs) [68,69]. From a functional point of view such a distribution of binding motifs makes sense, because these non-coding regions are less constrained in protein binding than the coding regions and $5^{\prime} \mathrm{UTR}$, in which excessive protein binding might interfere with function, e.g., translation. Importantly, RBPs execute their regulatory functions on both, coding and non-coding RNAs (ncRNAs), and might cooperate or compete with other post-transcriptional regulators, e.g., miRNAs, or might even be subjected to post-transcriptional control themselves. For example, association of proteins with lncRNAs can affect the localization and stability of both, the non-coding transcript as well as the protein. These interactions are of functional relevance for diverse cellular processes including, but not limited to transcriptional and epigenetic gene expression control, splicing, DNA damage signaling, tissue homeostasis and differentiation as well as cancer cell invasion and metastasis [70-77]. Furthermore, recent studies have identified several RBPs that regulate the processing and biogenesis of miRNAs and their precursors $[78,79]$. Because miRNAs preferentially target the $3^{\prime}$ UTRs within mRNAs, it is more and more realized that there might be some competition or even cooperation between RBPs and miRNAs as exemplified by the well-characterized oncofetal RBP Insulin-like growth factor 2 mRNA-binding protein 1 (IGF2BP1), which was shown to enhance the expression of oncogenic factors by interfering with miRNA-targeting $[58,80]$. The opposite was observed for tristetraprolin (TTP) and human antigen $\mathrm{R}$ (HuR), which cooperate with miR-16 or let-7, respectively, by recruiting target transcripts to the RNA-induced silencing complex (RISC) thereby enhancing miRNA-mediated gene silencing [81,82]. Intriguingly, in the context of $3^{\prime} \mathrm{UTR}$-dependent gene regulation, it was recently shown that the assembly of many protein complexes in eukaryotic cells occurs co-translationally whereat proteins of the same complex support each other's three-dimensional folding [83]. While the underlying molecular mechanism(s) are largely unclear, it has been suggested that RBPs, through their binding to the $3^{\prime}$ UTRs, might play a crucial role to enable proximity of two subunits near translating ribosomes [84]. This finding is well in line with other recent studies that established an important role for individual $3^{\prime}$ UTRs in mediating protein-protein interactions thereby regulating diverse protein features, including protein complex formation, posttranslational modifications as well as protein conformation in a coding-sequence independent manner. Importantly, RBPs and their binding to the respective $3^{\prime}$ UTRs was shown to be necessary for the 3'UTR-mediated effects [85-88].

We have summarized the classical as well as emerging hallmark functions of RBPs in Figure 1. Given their widespread impact on gene expression and signaling networks, mutations or defects in the expression or localization of RBPs can cause a broad range of diseases, e.g., neurodegeneration, obesity, hypertension, and cancer [55,89-96]. In the next paragraph, we will highlight selected examples of RBPs that have been shown to contribute to the malignancy of oral cancer, especially its metastatic features. 
RNA

\section{Transport \& Localisation}

HNRNPL SRSF3 IGF2BP3

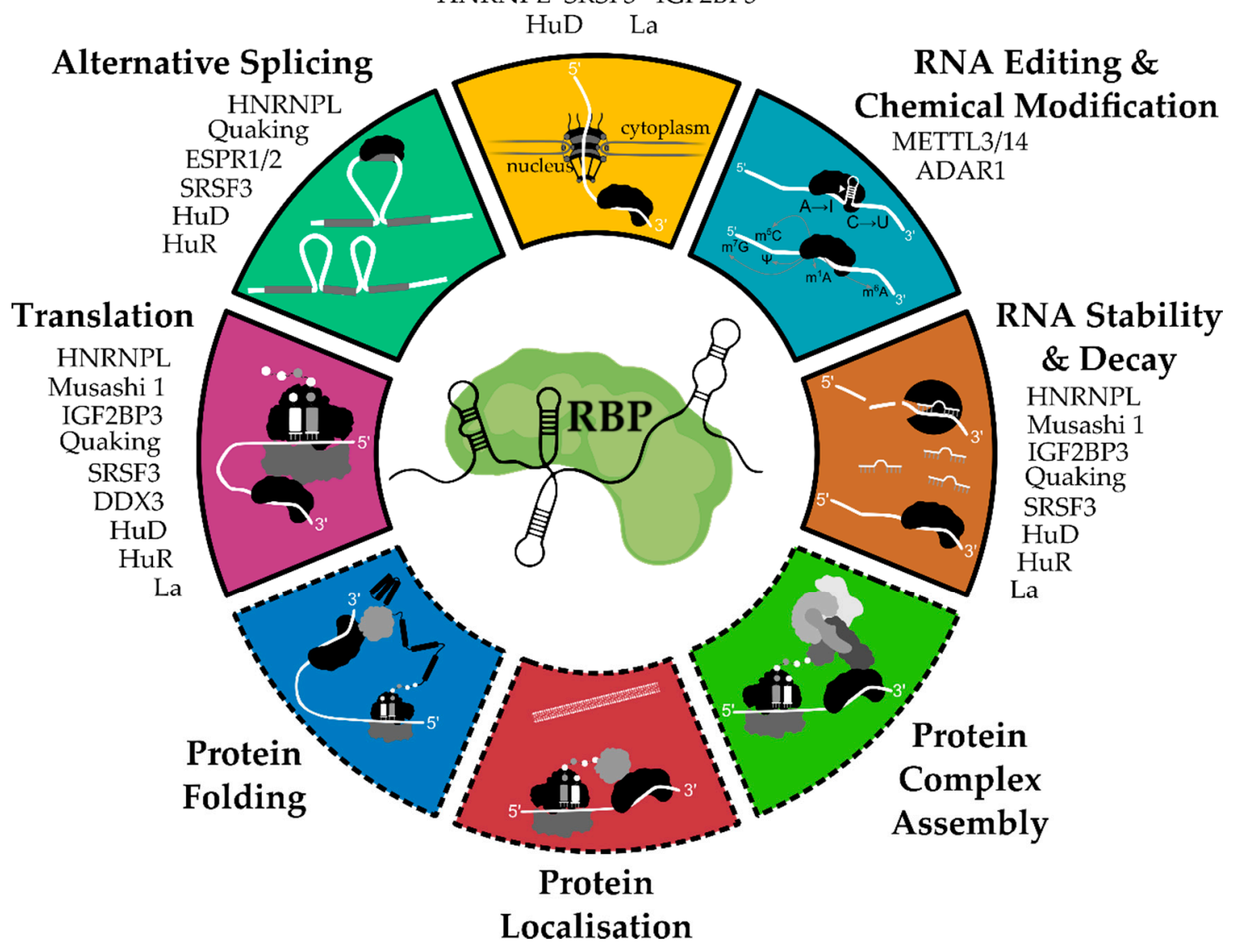

Figure 1. Functional hallmarks of RNA-binding proteins (RBPs). RBPs are important post-transcriptional regulators of gene expression. They are well-known to regulate RNA translation, splicing, transport, editing and chemical modification as well as turnover. Moreover, emerging functions of RBPs in co-translational protein complex assembly, protein localization and protein folding have been recently suggested. Hence, deregulated RBP activities can have broad effects on cellular homeostasis and are associated with several human diseases. Oral cancer-associated RBPs highlighted in this article have been assigned to relevant hallmark functionalities based on their established roles in human cancers as well as developmental processes.

\section{RBPs Associated with Migration, Invasion, and Metastasis in OSCC}

As mentioned earlier metastases are the major cause of cancer-associated death. However, the role and architecture of RBPs and RBP-controlled expression networks in the diverse steps of the metastatic cascade is only incompletely understood. Here, we introduce some examples of RBPs whose association with the malignant spread of oral cancer cells has been recently established.

\subsection{ADAR1}

The adenosine deaminase acting on RNA 1 (ADAR1) protein is involved in adenosine-to-inosine (A-to-I) editing in double-stranded RNA and has been implicated in several human cancers [97,98]. Because inosines are read as guanosines $(\mathrm{G})$, editing can enhance the complexity of the transcriptome and re-coding of the genetic information by the generation of non-synonymous codon changes or alternative splicing. RNA editing can also affect targeting or disrupt maturation of miRNAs [99]. In fact, a comparative whole genome expression microarray analysis revealed that ADAR1 fundamentally 
regulates miRNA processing, which was suggested to largely happen in an RNA binding-dependent, yet RNA editing-independent manner by regulating Dicer expression [100]. Another study could show that ADAR1 forms a complex with Dicer through direct protein-protein interactions which increases the maximum rate of pre-miRNA cleavage and facilitates RISC loading of mature miRNAs [101]. In line with this, a recent study could show that ADAR1 physically interacts with Dicer and promotes the maturation of oncogenic miRNAs in OSCC [102]. Moreover, the authors could show that high levels of ADAR1 in OSCC tissues are associated with primary tumor size, lymph node metastasis, stage as well as overall and disease-free survival. On the cellular level, ADAR1 was shown to promote proliferation, growth and stemness of OSCC cell lines. Moreover, overexpression of ADAR1 enhanced the migration and invasion phenotype of the cells and it was suggested that ADAR1 is involved in the EMT process of OSCC [102]. However, the function of ADAR1 and its clinical relevance in OSCC might depend on the ADAR1 protein isoform as well as its intracellular localization, which both warrants further investigations [103].

\section{2. $D D X 3$}

The ATP-dependent DEAD-box RNA helicase DDX3 is involved in multiple steps of RNA metabolism from transcription to translation control, and DDX3 participates in several signaling processes, e.g., innate immune response and Wnt signaling [104,105]. Mechanistically, the helicase activity of DDX3 as well as its interaction with factors of the translation initiation complex may facilitate translation, e.g., by resolving complex structures present in the $5^{\prime}$ UTR or by remodeling ribonucleoprotein complexes [106-108]. However, the impact of DDX3 on global translation remains controversial $[109,110]$. Similarly, the expression and function of DDX3 in human cancers is diversified, although DDX3 has been shown to modulate cell adhesion, motility and cancer cell metastasis via the Rac1 pathway [111,112]. Importantly, high expression levels of DDX3 in HNSCC correlated with lymph node metastasis and poor prognosis, and depletion of DDX3 in OSCC cells reduced their proliferation, invasion, and metastatic dissemination in vivo [107]. On the molecular level, DDX3 was shown to act coordinately with the cap-binding complex (CBC) and eukaryotic initiation factor 3 (eIF3) to enhance the translation of Activating transcription factor 4 (ATF4) and other upstream open reading frame (ORF)-containing mRNAs that together modulate EMT programs and promote metastasis [107]. Thus, targeting the novel DDX3-CBC-eIF3 translational complex might be a promising treatment strategy in OSCC.

\subsection{ELAVL1/HuR}

One of the best characterized RBPs in human cancer cells is HuR, the protein product of the embryonic lethal and abnormal vision gene ELAVL1. HuR, in contrast to its family members HuB (ELAVL2), HuC (ELAVL3) and HuD (ELAVL4), is ubiquitously expressed in human tissues and is a well-established regulator of post-transcriptional gene expression whose activity is not only controlled by abundance, but also by its subcellular localization [113-115]. In detail, under normal cellular and physiological conditions, HuR is primarily located in the nucleus where it can control splicing and alternative polyadenylation [116-118]. However, upon exposure to intrinsic or extrinsic stress, it can accumulate in the cytoplasm where it stabilizes and increases the translation of target mRNAs that contain adenine and uridine (AU)-rich elements (AREs) embedded in their 3'UTR [119]. RNA binding is achieved via three RNA recognition motifs (RRMs), whereas translocation is governed by the HuR nucleocytoplasmic shuttling sequence (HNS) located between the second and third RRM [115,120]. Importantly, chronic activation and cytoplasmic localization of HuR can support an inflammatory phenotype, partially due to the stabilization of mRNAs encoding proinflammatory cytokines and enzymes such as transforming growth factor (TGF)- $\beta$, tumor necrosis factor (TNF)- $\alpha$, interferone (IFN)- $\gamma$, cyclooxygenase (COX)-2 and others [121-123]. Consequently, HuR-dependent inflammation has also been linked to chronic diseases, e.g., pancreatitis, and is thought to underlie HuR's ability to contribute to many human malignancies including cancer $[115,123,124]$. In oral cancer it was shown 
that HuR is localized in the nucleus and cytoplasm of oral cancer cells and tissues, whereas normal oral tissues and cell lines contained HuR almost exclusively in the nucleus [125]. Moreover, loss-of-function experiments revealed an important role for $\mathrm{HuR}$ in the transport and stabilization of ARE-containing transcripts, such as cellular oncogene fos (c-FOS), avian myelocytomatosis virus oncogene cellular homolog (c-MYC), and COX-2 mRNAs. Furthermore, HuR was shown to regulate the expression of cell cycle-related proteins (cyclin A, cyclin B1, cyclin D, and cyclin-dependent kinase (CDK) 1) and in the case of CDK1 HuR was able to interact with its mRNA to stabilize it. Not surprisingly, the ability of oral cancer cells to grow in an anchorage-independent manner as well as their motile and invasive capabilities were reduced upon HuR depletion [126]. Analysis of HuR (and COX-2) in OSCC tumor tissues using immunohistochemistry demonstrated that cytoplasmic, but not nuclear HuR immunoreactivity was correlated with COX-2 expression $(p<0.025)$, grade $(p<0.014)$, lymph node $(p<0.050)$, and distant metastases $(p<0.025)$ as well as reduced survival $(p<0.023)$ [127]. Thus, cytoplasmic HuR expression can be considered an independent prognostic marker for poor outcomes in oral cancer, which might, at least partially, be due to its positive effect on COX-2, a pleiotropic cancer gene [128].

\subsection{ESRP1 and ESRP2}

Over the past decade RNA-sequencing technologies and sophisticated analysis pipelines have led to a wave of discoveries regarding the causes and functional relevance of alternative splicing, which has increased the awareness of its potential role in the development and progression of cancer and other diseases [129]. These analyses revealed that more than $95 \%$ of protein-coding genes in humans undergo some form of alternative splicing (exon skipping or inclusion of a cassette exon, alternative splice site choice, mutually exclusive exons, intron retention) in a cell type- or condition-specific manner, with at least $80 \%$ of these changes altering the protein-coding potential of the transcript or the presence of regulatory sequences in UTRs $[130,131]$. Importantly, the expansion of the proteome through alternative splicing is an essential driver of cell differentiation and fate decisions and contributes to the ability of cells to respond appropriately to signaling events, e.g., TGF- $\beta$-induced EMT $[42,132,133]$. Two well-known regulators of alternative splicing are the epithelial splicing regulatory proteins 1 and 2 (ESRP1 and ESRP2). Both proteins regulate alternative splicing events associated with epithelial phenotypes of cells, and the expression of both is reduced during EMT [134-136]. Mechanistically, ESRP1/2 regulate epithelium-specific splicing by binding of UGG- or GGU-rich sequences that are known as ESRP binding splicing enhancer (EBSE) and ESRP binding splicing inhibitor (EBSI) [42,134]. The location of the EBSE and EBSI elements relative to the alternatively spliced exons determines the outcome, i.e., exon inclusion or skipping. Exon skipping is favoured when ESRP binding sites are located at the $5^{\prime}$ end of, and/or within, the regulated exon, whereas ESRP binding at the $3^{\prime}$ end of regulated exons enhance exon inclusion [42]. Importantly, down-regulation of ESRP1/2 during TGF- $\beta$-induced EMT was shown to induce an isoform switch of fibroblast growth factor (FGF) receptors. This sensitizes cells to FGF- 2 and, through cooperation with TGF- $\beta$, enhances EMT leading to more aggressive phenotypes [137]. On the other hand, enforced overexpression of ESRP1 could suppress malignant phenotypes of colon and breast cancer cells $[138,139]$. However, whether ESRPs are generally tumor-promoting or inhibiting remains controversial [140]. Intriguingly, a recent study in OSCC revealed a high plasticity of ESRP expression during cancer cell invasion and metastasis [141]. In detail, 49 samples of human HNSCC tissues were examined to detect ESRP1/2 in different stages (normal tissue, dysplasia, carcinoma in situ, invasive carcinoma) and a higher expression level of both proteins was detected in dysplasia and carcinoma in situ compared to normal epithelium. Moreover, higher expression of ESRP1/2 was also detected in advanced OSCC and cancer nests in metastatic lymph nodes. In contrast, careful analysis revealed a loss of ESRP1 and ESRP2 expression in cancer cells that penetrated through the basement membrane into the stroma as well as in those cells that invaded from cancer nests into stromal tissues. Hence, down-regulation of ESRP1 and ESRP2 in OSCC might be restricted to cells that acquire a motile phenotype during cancer invasion [141]. These findings highlight 
the need for single-cell resolved data analyses to obtain a deeper understanding of the molecular changes contributing to cancer metastasis. Moreover, the authors identified distinct mechanisms of action of ESRP1 and ESRP2 in oral cancer cells. First, depletion of ESRP1 principally inhibited cell motility via regulation of actin dynamics. This was partially achieved by inclusion of exon $3 \mathrm{~b}$ in alternative splicing of Rac1 mRNA, thereby increasing expression of the Rac1b isoform upon ESRP1 depletion. Rac1b modulated actin dynamics to induce formation of long filopodia and augment cell motility. In contrast, depletion of ESRP2 strongly repressed E-cadherin mRNA and protein expression. Of note, levels of ZEB1 and ZEB2, two EMT-associated transcription factors that repress E-cadherin expression, were elevated upon ESRP2 silencing. However, it remains to be elucidated how ESRP2 is able to represses ZEB1/2 expression and whether splicing-independent mechanisms, e.g., regulation of miRNA biogenesis might underlie ESRP2 function in oral cancer cells [141]. Another interesting function of ESRP1/2 in OSCC was recently described in a study focusing on the oncogenic roles and biogenesis of a circular RNA (circRNA) called circUHRF1. The authors could show that this circRNA is able to promote proliferation, migration, invasion, and EMT in vitro as well as oral cancer cell growth in vivo by sponging miR-526b-5p and lifting c-MYC expression [142]. Of note, the circularisation and biogenesis of circUHRF1 was accelerated by ESRP1 binding to the flanking introns thereby enforcing a circUHRF1/miR-526b-5p/c-MYC/TGF- $\beta 1 /$ ESRP1 feedback loop. Given the controversial roles of ESRPs and the spatially fine-tuned expression of both proteins in OSCC tissues as mentioned before, it would be interesting to investigate, if this axis contributes to non-cell autonomous mechanisms of EMT and metastasis through the secretion of TGF- $\beta$ into the microenvironment.

\subsection{IGF2BP3}

The mammalian Insulin-like growth factor 2 mRNA-binding protein (IGF2BP) family comprises of three RBPs. Two members of the family, IGF2BP1 and IGF2BP3, are de novo synthesized in various human cancers and function as bona fide oncofetal proteins [143]. All family members share a conserved domain structure including two RRMs at the $\mathrm{N}$-terminus and four $\mathrm{C}$-terminal heterogeneous nuclear ribonucleoprotein (hnRNP) K homology (KH) domains, the latter being essential for RNA-binding and thereby determine the mainly cytoplasmic, granular distribution pattern of all three proteins [144]. Despite their high degree of structural similarity, the IGF2BP family members exhibit quite different expression patterns and exhibit distinct RNA-binding properties and presumably associate with variable target transcripts that might contain the putative consensus binding motif $\mathrm{CAUH}(\mathrm{H}=\mathrm{A}, \mathrm{U}$, or C) [145]. Importantly, all paralogues were shown to control the turnover, translation and/or transport of their target transcripts and there is the assumption that all IGF2BPs direct mRNA fate via cytoplasmic RNPs in which IGF2BPs might associate with other RBPs, mainly or exclusively in an RNA-dependent manner [144]. Functional studies over the last decades revealed that IGF2BPs modulate the expression of genes implicated in the control of cell proliferation, survival, chemo-resistance, and metastasis. Consistently, the expression of IGF2BP family members was reported to correlate with an overall poor prognosis and metastasis in various human cancers $[143,146]$. In OSCC, several studies specifically identified IGF2BP3 expression to be upregulated in oral squamous cell carcinoma [147-153]. However, all studies relied on a non-paralogue-specific antibody and some results have to be considered with great caution [146]. Nevertheless, several studies established IGF2BP3 as a predictor of lymph node status and metastasis and its expression was shown to correlate with an overall poor prognosis in OSCC [147-153]. On the cellular level, it has been reported that IGF2BP3 is specifically overexpressed at the invasive front of invasive OSCC cells and its depletion reduced the invasive capacity of oral cancer cells and impaired tumor growth in a mouse xenograft model [148,154]. A key target of IGF2BP3 in OSCC seems to be podoplanin (PDPN). PDPN is also specifically expressed at the invasive front of tumors and IGF2BP3 regulates the PDPN expression by binding to the $3^{\prime}$ UTR of the PDPN mRNA, thereby stabilizing the transcript [148]. Notably, both IGF2BP3 and PDPN expression was shown to correlate with lymph node metastasis in OSCC patients and IGF2BP3 downregulation inhibited invadopodia formation, extracellular matrix degradation, and tumor growth and invasiveness [148,154]. 
In addition, the expression of both IGF2BP3 and PDPN together was associated with bone invasion and the number of osteoclasts in patients with OSCC and IGF2BP3 or PDPN depletion inhibited the invasive capacity of OSCC cells in a three-dimensional culture system, tumorigenesis, and regional bone destruction in a xenograft mouse model [155]. Furthermore, IGF2BP3 was investigated in preoperative biopsy material and appeared to be predictive of perineural invasion in patients with OSCC and IGF2BP3 status was an independent predictor of death of patients with OSCC [156]. Although the detailed mechanisms that drive IGF2BP3 expression in oral cancer remain to be determined, a recent study identified epidermal growth factor (EGF) as an inducer of IGF2BP3 and PDPN expression [157]. However, additional studies are required to comprehensively map the RNA and protein interactome of IGF2BP3, and to characterize the function of the other IGF2BP family members in oral cancer.

\section{6. $\operatorname{LIN} 28 B$}

The LIN28B gene belongs to the lin-28 family that was initially discovered in Caenorhabditis elegans where it controls developmental timing [158]. In humans, the family is comprised of two members, namely LIN28A and LIN28B that are both able to bind RNA via their cold-shock domain and the two Cys-Cys-His-Cys (CCHC)-type zinc finger domain. In addition, LIN28B contains a nuclear and nucleolar localization signal responsible for its nuclear accumulation, whereas LIN28A is primarily located in the cytoplasm [159]. The difference in their intracellular localization underlies their partially overlapping, yet largely different cellular functions and mechanisms. For example, both paralogues were shown to inhibit let-7 miRNA biogenesis, although by distinct molecular mechanisms [160]. A huge body of evidence suggests that Lin28 proteins significantly contribute to pluripotency, reprogramming and tumorigenesis. They regulate cancer cell proliferation, metabolism, resistance to radiotherapy as well as chemotherapy and induce cancer stem cell (CSC) formation. Importantly, CSCs are associated with cancer development, progression, metastasis, recurrence and therapy resistance in HNSCC [159]. Intriguingly, Lin28A and Lin28B were found to be increased in OSCC and Kaplan-Meier analysis showed that patients with high Lin28B but not Lin28A expression had lower overall survival rates than those with low Lin28B expression [161]. In the line with this, stable overexpression of Lin28B in oral cancer cells promoted cell migration, invasion, colony formation, and tumor growth in vivo. While the precise molecular mechanism of Lin28B was not thoroughly investigated, the authors observed an increase of diverse and well-known regulators of cancer phenotypes, e.g., interleukin-6 (IL-6), high-mobility group AT-hook 2 (HMGA2), snail family transcriptional repressor 1 (SNAI1), TWIST, vascular endothelial growth factor (VEGF), and baculoviral IAP repeat containing 5 (BIRC5) [161]. Nevertheless, the clinical relevance of Lin28B could be confirmed by other studies. For example, Wang and colleagues also found that high Lin28B expression in OSCC was significantly associated with short overall survival, and a multivariate survival analysis revealed that Lin28B expression status was a critical independent prognostic marker for overall survival of OSCC patients [162]. Notably, the authors could show that Lin28B abundance was associated with tumor size as well as cervical lymph nodes metastasis [162]. Another recent study used tumor tissue samples and matched adjacent non-cancerous tissues as well as lymph node metastatic lesions from OSCC patients and measured Lin28B transcript levels via quantitative real-time polymerase chain reaction (qRT-PCR) [163]. Again, higher Lin28B levels were present in tumors compared to normal tissues with an additional increase seen in metastatic samples. Depletion of Lin28B attenuated carcinogen-induced proliferation, migration, and invasiveness of oral cancer cell lines in vitro, yet the downstream targets of Lin28B remain elusive [163]. In order to investigate Lin28B and its role in OSCC cancer stem cells, Chien et al. analyzed and compared the expression levels of Lin28B in nine pairs of tumorous and non-tumorous tissues of oral cancer patients using immunohistochemistry as well as qRT-PCR, confirming the upregulation in transformed tissues [164]. Moreover, the authors found that cells expressing CSC markers, i.e., cluster of differentiation (CD) 44 and aldehyde dehydrogenase 1 (ALDH1), had high mRNA expression levels of Lin28B. Subsequent functional analyses revealed that the Lin28B/Let-7 pathway positively regulates POU class 5 homeobox 1 (POU5F1) and SRY-box transcription factor 2 (SOX2) expression 
in OSCC, thereby inducing a reprogramming-like phenomenon, switching non-CSCs to CSCs with tumor-initiating and self-renewal properties. By suppressing let-7, Lin28B enhances the expression of AT-rich interaction domain molecule 3B (ARID3B) and HMGA2 proteins, which directly regulate POU5F1 and SOX2 promoter activity, respectively [164]. Taken together, these studies highlight the importance of Lin28B in OSCC metastases and establish this RBP as an important prognostic marker as well as therapeutic target in oral cancer.

\subsection{METTL3-METTL14 Complex}

In the last couple of years, chemical modifications in RNA-also referred to as 'RNA epigenetics' or the 'epitranscriptome' - have been extensively studied and their dynamic distribution as well as the impact of modified bases on the metabolism and fate of both coding and non-coding transcripts has been revealed [165-167]. N6-Methyladenosine (m6A) accounts for the most abundant internal modification in eukaryotic mRNA where it is specifically found in the consensus DRACH motif (where D = A/G/U, $\mathrm{R}=\mathrm{A} / \mathrm{G}$, and $\mathrm{H}=\mathrm{A} / \mathrm{C} / \mathrm{U}$ ). It was shown to control gene expression in diverse physiological and pathophysiological processes by tuning RNA stability, splicing, and translation [168]. The vital roles of m6A in diverse biological processes are dependent on many RBPs with catalytic and non-catalytic roles as readers, writers and erasers of m6A [169,170]. The methyltransferase-like 3 and 14 (METTL3 and METTL14) proteins are part of the main RNA methyltransferase complex, which is comprised of METTL3, METTL14, and Wilms' tumor 1-associated protein (WTAP). Importantly, METTL3 is the enzymatic component of the complex whereas METTL14 acts as an allosteric activator and plays a structural role critical for substrate recognition and their genetic ablation in mouse embryonic stem cells led to a loss of $99 \%$ of all m6A in poly(A) RNA [171-174]. Of note, oncogenic roles for METTL3 and METTL14 have been described in several human cancers including acute myeloid leukemia (AML), lung and liver cancer in which they increase the expression of oncogenes, e.g., MYC, SNAI1, and EGFR, or enhance the degradation of tumor suppressors, e.g., suppressor of cytokine signaling 2 (SOCS2) to drive tumor growth signaling. However, the role of the METTL3-METTL14 complex might be dependent on the cancer type, and also tumor suppressive functions have been described $[165,168]$. However, the contributions of $\mathrm{m} 6 \mathrm{~A}$ as well as the respective reader, writer and eraser proteins for the development and progression of OSCC are not well understood yet. Only recently the expression profiles of 13 m6A-related genes in 317 OSCC and 32 normal samples from The Cancer Genome Atlas (TCGA) database had been analyzed and found a significantly higher expression of eight genes, including METTL3 and METTL14, in tumor tissues. Furthermore, an increase of m6A levels in total tumor RNA could be detected using an antibody-based quantification kit [175]. The upregulation of METTL3 in oral cancer was also seen in two additional studies that also report a correlation of METTL3 expression with poor prognosis of OSCC patients $[176,177]$. Both studies detected similar cellular phenotypes, i.e., METTL3 promoted the proliferation, self-renewal, invasion, and migration of OSCC cells in vitro, as well as tumor growth and metastasis in vivo $[176,177]$. In addition, a genetically modified mouse model revealed an essential role of Mettl3 in chemical-induced oral carcinogenesis [176]. However, both studies discovered varying mechanisms, which are not mutually exclusive and might simply reflect the overall diverse molecular targets and modes of action of METTL3 and/or m6A. In detail, Zhao and colleagues performed methylated RNA immunoprecipitation sequencing (MeRIP-seq) and identified the c-MYC mRNA as a m6A-modified transcript whose stability is positively regulated by the m6A writer METTL3 and the YTH domain family member 1 (YTHDF1) protein acting as m6A reader [177]. Hence, the METTL3/m6A/YTHDF1/c-Myc axis might be a novel and promising target for OSCC therapy. Alternatively, METTL3-catalysed methylation of epigenetic regulators might also represent a novel targeting option. Specifically, Liu and colleagues could show that METTL3 is responsible for the deposition of m6A marks in the $3^{\prime} \mathrm{UTR}$ of the B lymphoma Mo-MLV insertion region 1 homolog (BMI1) mRNA [176]. BMI1, a CSC marker and component of the Polycomb Repressive Complex 1 (PRC1) that is responsible for chromatin remodeling and epigenetic gene silencing, has been previously shown to promote chemoresistance and metastasis in HNSCC and plays an important 
role in the progression and prognosis of OSCC [178]. Here, METTL3, in cooperation with the m6A reader IGF2BP1, enhanced the translation of BMI1 in oral cancer cells, which is thought to underlie the observed cellular phenotypes upon METTL3 depletion or overexpression, although this remains to be formally proven $[176,179]$. Furthermore, the crosstalk between METTL3-dependent changes in epitranscriptome and their impact on the epigenetic modifications found in the oral cancer genome, including a potentially altered chromatin organization, need to be analyzed in more detail in the future. Nevertheless, the m6A pathway and its catalytic components, e.g., METTL3, represent interesting and druggable targets to altered RNA metabolism in oral cancer cells.

In summary, several individual RBPs have been identified as important regulators of oral cancer cell phenotypes as well as prognostic markers in OSCC. The herein presented examples highlight the broad variety of RBP functions and mechanisms of activation and establish these RBPs as clinically relevant targets in OSCC. Additional RBPs with a role in oral cancer cell migration, invasion, and metastasis are summarized in Table 1. In the following paragraph we aim to provide a brief overview about the recently developed targeting strategies.

Table 1. Additional RBPs with a role in oral cancer cell migration, invasion, and metastasis.

\begin{tabular}{|c|c|c|}
\hline $\mathbf{R B P}$ & Function \& Mechanism & Reference \\
\hline$H u D$ & $\begin{array}{l}\text { expression associated with lymph node metastasis and mode } \\
\text { of invasion; } \\
\text { depletion reduced invasiveness of cells and transcript levels of } \\
\text { VEGF-A, VEGF-D, matrix metalloproteinase-2 (MMP-2) } \\
\text { and MMP-9 }\end{array}$ & [180] \\
\hline HNRNPL & $\begin{array}{l}\text { overexpressed in OSCC compared to normal oral } \\
\text { mucosa tissue; } \\
\text { depletion reduced proliferation, viability, migration and } \\
\text { in vivo growth; } \\
\text { regulates SRSF3 RNA expression \& alternative splicing of } \\
\text { exon } 4\end{array}$ & [181] \\
\hline \multirow[b]{2}{*}{$\begin{array}{c}\text { Musashi } 1 \\
\text { (MSI1) }\end{array}$} & $\begin{array}{l}\text { higher expression in higher stages and poorly differentiated } \\
\text { tumors; independent prognostic marker of overall and } \\
\text { disease-free survival }\end{array}$ & [182] \\
\hline & $\begin{array}{l}\text { higher MSI1 mRNA level in OSCC compared to matched } \\
\text { healthy tissue; } \\
\text { depletion reduced proliferation, invasion, migration, and } \\
\text { in vivo growth; } \\
\text { might regulate c-MYC expression and STAT3 activation }\end{array}$ & [183] \\
\hline \multirow{2}{*}{$\begin{array}{c}\text { Quaking } \\
(Q K I)\end{array}$} & $\begin{array}{l}\text { lower expression in OSCC compared to normal } \\
\text { mucosal samples; } \\
\text { overexpression reduced stemness, tumor growth } \\
\text { and metastasis; } \\
\text { depletion enhanced Sox } 2 \text { mRNA stability and expression }\end{array}$ & [184] \\
\hline & $\begin{array}{l}\text { low expression in HNSCC resulted in shorter overall survival; } \\
\text { targeted by miR- } 200 \text { family; knockdown induced EMT and } \\
\text { enhanced migration and invasion in vitro and tumor growth } \\
\text { and metastasis in vivo; }\end{array}$ & [185] \\
\hline SRSF3 & $\begin{array}{l}\text { up-regulated in moderate or severe dysplasia tissues } \\
\text { compared with normal oral mucosal tissues, and higher grade } \\
\text { cancers express more SRSF3; expression correlated with lymph } \\
\text { node metastasis and its depletion reduced EMT-related genes } \\
\text { SNAI2 and N-cadherin }\end{array}$ & [186] \\
\hline$L a$ & $\begin{array}{l}\text { overexpressed in OSCC tissue compared to normal } \\
\text { epithelial tissue; } \\
\text { depletion inhibited proliferation, migration and invasion; } \\
\text { knockdown reduced MMP- } 2 \text { and } \beta \text {-catenin protein expression }\end{array}$ & [187] \\
\hline
\end{tabular}




\section{Therapeutic Targeting Options for RBPs Involved in Oral Cancer Progression}

In this final chapter we will focus on small molecules and chemistry-based strategies to target OSCC-associated RBPs. We will not discuss other genetic or non-genetic option, e.g., gene therapy, small interfering RNA (siRNA), circular RNAs, aptamers, or RNA-targeted therapies, which were recently discussed elsewhere $[188,189]$.

Small molecules have been developed to target disease-related proteins like ion channels, G-protein-coupled receptors, nuclear receptors, and kinases and these molecules are commonly and successfully used as therapeutics in clinical applications [190]. However, the target space ( $\sim 700$ proteins) of small molecules with regulatory approval is rather limited and currently accounts for less than $0.5 \%$ of the human proteome. Similar to most transcription factors, RBPs are generally considered to be difficult to target and only a limited number of small molecules have been discovered that inhibit the function of RBPs involved in oral cancer progression (Table 2).

Table 2. Inhibitors of RBPs involved in oral cancer progression.

\begin{tabular}{|c|c|c|c|}
\hline Target RBP & Compound & Mode of Action & Reference \\
\hline$A D A R 1$ & 8-Azaadenosine & Inhibits RNA editing activity & [191] \\
\hline \multirow{6}{*}{$D D X 3$} & RK-33 & Inhibits helicase or ATPase activity & [192-194] \\
\hline & NZ51 & Inhibits helicase activity & {$[195,196]$} \\
\hline & FE15/FE87/FE98/FE109 & Inhibit the ATPase activity & {$[197,198]$} \\
\hline & Compounds 1 \& 3 & Target the RNA binding site & [199] \\
\hline & Compounds 6 \& 8 & Inhibit helicase and ATPase activity & [199] \\
\hline & Ketorolac salt & Reduces DDX3 expression and inhibits ATPase activity & [200] \\
\hline \multirow{7}{*}{$H u R$} & MS-444, Okicenone, Dehydromutactin & $\begin{array}{l}\text { Interfere with formation of HuR dimers and thereby } \\
\text { RNA binding }\end{array}$ & [201] \\
\hline & Quercetin, b-40 & Inhibit HuR:ARE (TNF- $\alpha$ ) complex formation & [202] \\
\hline & Mitoxantrone & Inhibit HuR:ARE (TNF- $\alpha$ ) complex formation & [203] \\
\hline & dihydrotanshinone-I & Inhibits binding of HuR to several RNAs & [204] \\
\hline & Compound 10 & Disrupts HuR oligomerization & [205] \\
\hline & CMLD-2 & $\begin{array}{l}\text { Inhibits binding of HuR to ARE-containing target } \\
\text { RNAs (Bcl-2, MSI1 and XIAP) }\end{array}$ & [206] \\
\hline & Azaphilone-9 & $\begin{array}{c}\text { Inhibits HuR:ARE interaction by competitive binding } \\
\text { in the RNA-binding cleft }\end{array}$ & [207] \\
\hline \multirow{2}{*}{ IGF2BP3 } & d-ICD & Inhibits IGF2BP3 expression & [208] \\
\hline & JQ1, iBET & Inhibit IGF2BP3 expression & {$[209,210]$} \\
\hline \multirow{6}{*}{ LIN28 } & Compound 1 & Inhibits LIN28-pre-let-7 interaction & [211] \\
\hline & Compound 1632 & Inhibits LIN28-pre-let-7 interaction & [212] \\
\hline & 6-hydroxy-DL-DOPA, SB/ZW/0065 & Inhibit LIN28-pre-let-7 interaction & {$[213]$} \\
\hline & LI38 (TPEN), LI71 & Inhibit LIN28-mediated oligouridylation of let-7 & [214] \\
\hline & KCB170522, Luteolin & Inhibit LIN28-pre-let-7 interaction & [215] \\
\hline & CCG-233094, CCG-234459 & Inhibit LIN28-pre-let-7 interaction & [216] \\
\hline METTL3 & $\begin{array}{l}\text { ribofuranuronic acid analogues of } \\
\text { adenosine, adenosine analogue with a } \\
\text { tetrahydropyran ring }\end{array}$ & $\begin{array}{l}\text { Competitors of S-adenosyl-L-methionine (SAM) for } \\
\text { METTL3 binding }\end{array}$ & [217] \\
\hline \multirow{4}{*}{ MSI1 } & Inhibitor \#1-3 & Inhibit RNA binding activity of MSI1/2 & [218] \\
\hline & Ro $08-2750$ & Inhibits RNA binding activity of MSI1/2 & [219] \\
\hline & Oleic acid & $\begin{array}{l}\text { Induces a conformational change that prevents RNA } \\
\text { association }\end{array}$ & [220] \\
\hline & (-)-gossypol & $\begin{array}{c}\text { Interacts with RNA binding pocket and blocks } \\
\text { MSI1-RNA interaction }\end{array}$ & [221] \\
\hline$L a$ & HBSC-11 & Reduced La mRNA and protein levels & [222] \\
\hline SRSF3 & Palmitic Acid & $\begin{array}{l}\text { Increases neddylation and degradation of } \\
\text { SRSF3 protein }\end{array}$ & [223] \\
\hline
\end{tabular}

A widely applied strategy to interfere with the function of an RBP is to modulate the interaction with its key coding or non-coding target RNA that is thought to be essential for the disease-related function of the RBP. This can be achieved either via targeting the RNA or the RBP directly. RNA-targeting strategies, which include nucleotide-based agents that target unstructured regions of RNA as well as small molecules that bind directly to structured RNAs are showing promising clinical success and 
have been discussed elsewhere [188,224,225]. In contrast, RBP-targeting approaches remain largely underdeveloped. Major hurdles that make it challenging to obtain small molecules that specifically and effectively inhibit RBPs through a competitive binding mechanism are: (i) the strong electrostatic attraction between the negatively charged RNA and the positively charged binding domains of RBPs, (ii) the large interacting surface involved in many protein-RNA interactions, and (iii) the commonly used and conserved structures of the RBDs that are present in many RBPs and could cause off-target binding of the small molecules. Hence, most small molecule inhibitors of RBPs have weak, micromolar-range inhibitory potency, and their proteome-wide selectivity is often unknown. Of note, many of the RBP-targeting small molecules contain ring systems and off-target binding to other proteins is very likely [226]. For example, the natural product (-)-gossypol was identified as a high-affinity binder and inhibitor of MSI1 [221]. However, gossypol was also shown to bind to the really interesting new gene (RING) domain of mouse double minute 2 (MDM2) as well as to inhibit the tyrosine kinase activity of wild-type and mutant EGFR [227-229]. Moreover, the LIN28 inhibitor compound 1632 was shown to have micromolar binding affinity for the bromodomains of bromodomain-containing protein 4 (BRD4) and CREB-binding protein (CREBBP) [212]. Similar off-target effects might be found for other RBP inhibitors and might be responsible for their biological activities and observed effects on cell growth and other cancer phenotypes. Hence, more rigorous binding and specificity analyses should be implemented to obtain small molecules with high affinity and selectivity for individual RBPs. Furthermore, novel screening approaches and targeting concepts should be developed and tested considering the following points:

First, small molecule inhibitors of RBPs are commonly developed from hits initially identified in high-throughput screen and the chemical space covered in the screening libraries will therefore determine the biological activity and specificity of the hit compound, and ultimately the success of the screen. Thus, more complex and diverse libraries should be used in order to retrieve compounds with new biological activities against RBPs. To this end, libraries should include both protein-targeting and RNA-targeting molecules to ensure that RBP-RNA interactions are comprehensively interrogated. Second, the structures of RBPs, both in the presence and absence of their RNA substrate(s) should be systematically solved and catalogued. This will allow subsequent hit optimization by structure-activity relationship analysis and will ultimately shift the discovery of RBP inhibitors from screening-based approaches towards rational drug design-based approaches.

Second, the screening goals should be re-evaluated. For example, instead of aiming to identify small molecules that compete with RNA for binding to RBPs, it might be possible, e.g., by leveraging structural information, to identify allosteric binding pocket in RBPs that could be targeted by small molecules to block functional relevant conformational changes in RBPs. Additionally, unbiased screening to identify high-affinity binders irrespective of their binding sites on the RBP might enable the development of novel, chimeric molecules, so called proteolysis targeting chimeras (PROTACs) that could be used to induce proteasomal degradation of the target RBP [230].

Another aspect that should be considered in the design of future screening and targeting strategies is the dual functioning of some RBPs. For example, RBPs might not only act by modulating RNA metabolism, but might also bind to DNA and other proteins, or contain (pseudo)kinase and RING domains, which suggest non-canonical, potentially RNA-independent functions and novel options to modulate the activity of RBPs [231-234]. Furthermore, several RNA-dependent protein complexes that might comprise of direct and indirect RNA binders have been recently identified [235]. Disruption of these complexes by interfering with protein-protein interactions could offer an alternative targeting approach [236].

Last but not least, functional genetic screens could be used to identify synthetic vulnerabilities that could be exploited to target cancer cells that show an altered expression or mutations in RBP genes [237-240]. 


\section{Conclusions}

RNA-binding proteins comprise a huge and diverse class of important regulators of cellular plasticity and homeostasis. Their significant contribution to disease phenotypes has been broadly established. However, the therapeutic targeting of RBPs remains challenging. Thus, future research endeavors should try to identify disease-specific RBP-dependencies, explore indirect (synthetic) vulnerabilities, and develop innovative targeting approaches or leverage existing concepts to make this class of proteins accessible for RBP-directed clinical interventions.

Author Contributions: Conceptualization, T.G.; writing—original draft preparation, J.W., J.R., M.H. and T.G.; writing - review and editing, J.W., J.R., V.K., M.K., A.W.E., M.H. and T.G.; visualization, J.W., J.R. and V.K.; supervision, T.G.; project administration, T.G. All authors have read and agreed to the published version of the manuscript.

Funding: We acknowledge the financial support within the funding program Open Access Publishing by the German Research Foundation (DFG).

Acknowledgments: We apologize to all scientists whose important work could not be cited in this review due to space constraints. This article was supported by funds from the intramural Wilhelm-Roux-Programme of the Medical Faculty, Martin-Luther-University Halle-Wittenberg. The Figure was created with BioRender.com.

Conflicts of Interest: The authors declare no conflict of interest.

\section{Abbreviations}

A

ADAR1

ALDH1

AML

ARE

ARID3B

ATF4

BIRC5

BMI1

BRD4

CBC

CD

CDK

CDKN2A

c-FOS

circRNA

c-MYC

COX

CREBBP

CSC

DDX3

EBSE

EBSI

EGF

EGFR

eIF3

ELAVL

EMT

ESRP
Adenosine

Adenosine deaminase acting on RNA 1

Aldehyde dehydrogenase 1

Acute myeloid leukemia

(AU)-rich element

AT-rich interaction domain molecule 3B

Activating transcription factor 4

Baculoviral IAP Repeat Containing 5

B lymphoma Mo-MLV insertion region 1 homolog

Bromodomain-containing protein 4

Cap-binding complex

Cluster of differentiation

Cyclin-dependent kinase

Cyclin dependent kinase inhibitor 2A

cellular oncogene fos

circular RNA

Avian myelocytomatosis virus oncogene cellular homolog

Cyclooxygenase

CREB-binding protein

Cancer stem cell

DEAD Box Protein 3

ESRP binding splicing enhancer

ESRP binding splicing inhibitor

Epidermal growth factor

Epithelial growth factor receptor

eukaryotic initiation factor 3

Embryonic lethal and abnormal vision gene

Epithelial-to-mesenchymal transition

Epithelial splicing regulatory protein 
FGF Fibroblast growth factor

HMGA2 High-mobility group AT-hook 2

hnRNP heterogeneous nuclear ribonucleoprotein

HNRNPL Heterogeneous nuclear ribonucleoprotein L

HNS HuR nucleocytoplasmic shuttling sequence

HNSCC Head and neck squamous cell carcinoma

HPV Human papilloma virus

$\mathrm{HuB} \quad \mathrm{Hu}$ antigen $\mathrm{B}$

HuC Hu antigen C

HuD Hu antigen D

HuR Human antigen $\mathrm{R}$

I Inosine

IFN Interferone

IGF2BP Insulin-like growth factor 2 mRNA binding protein

IL-6 Interleukin 6

JAK Janus kinase

KH K homology

La Small RNA binding exonuclease protection factor La

lncRNA long non-coding RNA

M6A N6-Methyladenosine

MDM2 Mouse double minutes 2

MeRIP-seq Methylated RNA immunoprecipitation sequencing

METTL Methyltransferase-like

miRNA microRNA

mRNA messenger RNA

MSI1 Musashi1

mTOR mammalian target of rapamycin

ncRNA non-coding RNA

ORF Open reading frame

OSCC Oral squamous cell carcinoma

PDPN Podoplanin

PI3K Phosphatidylinositol-3-kinase

POU5F1 POU class 5 homeobox 1

PRC1 Polycomb repressive complex 1

PROTAC Proteolysis Targeting Chimeras

QKI Quaking

RB1 Retinoblastoma-associated protein 1

RBD RNA-binding domain

RBL1/2 Retinoblastoma-like protein 1

RBP RNA-binding protein

RING Really Interesting New Gene

RISC RNA-induced silencing complex

RRM RNA recognition motifs

SNAI1 Snail family transcriptional repressor 1

SOCS Suppressor of cytokine signaling

SOX2 SRY-Box transcription factor 2

SRSF3 Serine and arginine rich splicing factor 3

STAT Signal transducer and activator of transcription

TCGA The Cancer Genome Atlas

TGF Transforming growth factor

TNF Tumor necrosis factor

TP53 Tumor protein 53 


$\begin{array}{ll}\text { TTP } & \text { Tristetraprolin } \\ \text { UTR } & \text { Untranslated region } \\ \text { VEGF } & \text { Vascular endothelial growth factor } \\ \text { WTAP } & \text { Wilms' tumor 1-associated protein } \\ \text { YTHDF1 } & \text { YTH domain family member } \\ \text { ZEB } & \text { Zinc finger E-box binding homeobox }\end{array}$

\section{References}

1. Bray, F.; Ferlay, J.; Soerjomataram, I.; Siegel, R.L.; Torre, L.A.; Jemal, A. Global cancer statistics 2018: GLOBOCAN estimates of incidence and mortality worldwide for 36 cancers in 185 countries. CA Cancer J. Clin. 2018, 68, 394-424. [CrossRef] [PubMed]

2. Miranda-Filho, A.; Bray, F. Global patterns and trends in cancers of the lip, tongue and mouth. Oral. Oncol. 2020, 102, 104551. [CrossRef] [PubMed]

3. Melchers, L.J.; Schuuring, E.; van Dijk, B.A.; de Bock, G.H.; Witjes, M.J.; van der Laan, B.F.; van der Wal, J.E.; Roodenburg, J.L. Tumour infiltration depth $\geq 4 \mathrm{~mm}$ is an indication for an elective neck dissection in pT1cN0 oral squamous cell carcinoma. Oral. Oncol. 2012, 48, 337-342. [CrossRef] [PubMed]

4. Tang, X.H.; Scognamiglio, T.; Gudas, L.J. Basal stem cells contribute to squamous cell carcinomas in the oral cavity. Carcinogenesis 2013, 34, 1158-1164. [CrossRef] [PubMed]

5. Vig, N.; Mackenzie, I.C.; Biddle, A. Phenotypic plasticity and epithelial-to-mesenchymal transition in the behaviour and therapeutic response of oral squamous cell carcinoma. J. Oral. Pathol. Med. 2015, 44, 649-655. [CrossRef] [PubMed]

6. de Camargo Cancela, M.; de Souza, D.L.; Curado, M.P. International incidence of oropharyngeal cancer: A population-based study. Oral. Oncol. 2012, 48, 484-490. [CrossRef] [PubMed]

7. Graham, S.; Dayal, H.; Rohrer, T.; Swanson, M.; Sultz, H.; Shedd, D.; Fischman, S. Dentition, diet, tobacco, and alcohol in the epidemiology of oral cancer. J. Nat. Cancer Inst. 1977, 59, 1611-1618. [CrossRef]

8. Muttagi, S.S.; Chaturvedi, P.; Gaikwad, R.; Singh, B.; Pawar, P. Head and neck squamous cell carcinoma in chronic areca nut chewing Indian women: Case series and review of literature. Ind. J. Med. Paediatr. Oncol. 2012, 33, 32-35. [CrossRef]

9. Alsahafi, E.; Begg, K.; Amelio, I.; Raulf, N.; Lucarelli, P.; Sauter, T.; Tavassoli, M. Clinical update on head and neck cancer: Molecular biology and ongoing challenges. Cell Death Dis. 2019, 10, 540. [CrossRef]

10. Kang, H.; Kiess, A.; Chung, C.H. Emerging biomarkers in head and neck cancer in the era of genomics. Nat. Rev. Clin. Oncol. 2015, 12, 11-26. [CrossRef]

11. Cancer Genome Atlas Network. Comprehensive genomic characterization of head and neck squamous cell carcinomas. Nature 2015, 517, 576-582. [CrossRef] [PubMed]

12. Jayasurya, R.; Sathyan, K.M.; Lakshminarayanan, K.; Abraham, T.; Nalinakumari, K.R.; Abraham, E.K.; Nair, M.K.; Kannan, S. Phenotypic alterations in Rb pathway have more prognostic influence than p53 pathway proteins in oral carcinoma. Mod. Pathol. 2005, 18, 1056-1066. [CrossRef] [PubMed]

13. Lee, S.H.; Do, S.I.; Lee, H.J.; Kang, H.J.; Koo, B.S.; Lim, Y.C. Notch1 signaling contributes to stemness in head and neck squamous cell carcinoma. Lab. Investig. 2016, 96, 508-516. [CrossRef] [PubMed]

14. Porcheri, C.; Meisel, C.T.; Mitsiadis, T. Multifactorial Contribution of Notch Signaling in Head and Neck Squamous Cell Carcinoma. Int. J. Mol. Sci. 2019, 20, 1520. [CrossRef] [PubMed]

15. Sessions, D.G.; Spector, G.J.; Lenox, J.; Parriott, S.; Haughey, B.; Chao, C.; Marks, J.; Perez, C. Analysis of treatment results for floor-of-mouth cancer. Laryngoscope 2000, 110, 1764-1772. [CrossRef]

16. Sim, Y.C.; Hwang, J.H.; Ahn, K.M. Overall and disease-specific survival outcomes following primary surgery for oral squamous cell carcinoma: Analysis of consecutive 67 patients. J. Korean Assoc. Oral Maxillofac. Surg. 2019, 45, 83-90. [CrossRef]

17. Ries, L.K.G.; Hankey, B.F.; Miller, B.A.; Harras, A.; Edwards, B.K. SEER Cancer Statistics Review, 1973-1994; US Department of Health and Human Services, National Institutes of Health, Eds.; Bethesda: Rockville, MD, USA, 1997; Volume NIH publication no. 97-2789.

18. Duprez, F.; Berwouts, D.; De Neve, W.; Bonte, K.; Boterberg, T.; Deron, P.; Huvenne, W.; Rottey, S.; Mareel, M. Distant metastases in head and neck cancer. Head Neck 2017, 39, 1733-1743. [CrossRef] 
19. Noguti, J.; De Moura, C.F.; De Jesus, G.P.; Da Silva, V.H.; Hossaka, T.A.; Oshima, C.T.; Ribeiro, D.A. Metastasis from oral cancer: An overview. Cancer Genom. Proteom. 2012, 9, 329-335.

20. Okura, M.; Aikawa, T.; Sawai, N.Y.; Iida, S.; Kogo, M. Decision analysis and treatment threshold in a management for the N0 neck of the oral cavity carcinoma. Oral. Oncol. 2009, 45, 908-911. [CrossRef]

21. Greenberg, J.S.; Fowler, R.; Gomez, J.; Mo, V.; Roberts, D.; El Naggar, A.K.; Myers, J.N. Extent of extracapsular spread: A critical prognosticator in oral tongue cancer. Cancer 2003, 97, 1464-1470. [CrossRef]

22. Leemans, C.R.; Tiwari, R.; Nauta, J.J.; van der Waal, I.; Snow, G.B. Regional lymph node involvement and its significance in the development of distant metastases in head and neck carcinoma. Cancer 1993, 71, 452-456. [CrossRef]

23. Gowen, G.F.; Desuto-Nagy, G. The incidence and sites of distant metastases in head and neck carcinoma. Surg. Gynecol. Obstet. 1963, 116, 603-607. [PubMed]

24. Kotwall, C.; Sako, K.; Razack, M.S.; Rao, U.; Bakamjian, V.; Shedd, D.P. Metastatic patterns in squamous cell cancer of the head and neck. Am. J. Surg. 1987, 154, 439-442. [CrossRef]

25. O'Brien, P.H.; Carlson, R.; Steubner, E.A., Jr.; Staley, C.T. Distant metastases in epidermoid cell carcinoma of the head and neck. Cancer 1971, 27, 304-307. [CrossRef]

26. Adel, M.; Kao, H.K.; Hsu, C.L.; Huang, J.J.; Lee, L.Y.; Huang, Y.; Browne, T.; Tsang, N.M.; Chang, Y.L.; Chang, K.P. Evaluation of Lymphatic and Vascular Invasion in Relation to Clinicopathological Factors and Treatment Outcome in Oral Cavity Squamous Cell Carcinoma. Med. Baltim. 2015, 94, e1510. [CrossRef]

27. Jardim, J.F.; Francisco, A.L.; Gondak, R.; Damascena, A.; Kowalski, L.P. Prognostic impact of perineural invasion and lymphovascular invasion in advanced stage oral squamous cell carcinoma. Int. J. Oral. Maxillofac. Surg. 2015, 44, 23-28. [CrossRef]

28. Rahima, B.; Shingaki, S.; Nagata, M.; Saito, C. Prognostic significance of perineural invasion in oral and oropharyngeal carcinoma. Oral. Surg. Oral Med. Oral Pathol. Oral Radiol. Endod. 2004, 97, 423-431. [CrossRef]

29. Varsha, B.K.; Radhika, M.B.; Makarla, S.; Kuriakose, M.A.; Kiran, G.S.; Padmalatha, G.V. Perineural invasion in oral squamous cell carcinoma: Case series and review of literature. J. Oral Maxillofac. Pathol. 2015, 19, 335-341. [CrossRef]

30. Valastyan, S.; Weinberg, R.A. Tumor metastasis: Molecular insights and evolving paradigms. Cell 2011, 147, 275-292. [CrossRef]

31. LaFave, L.M.; Kartha, V.K.; Ma, S.; Meli, K.; Del Priore, I.; Lareau, C.; Naranjo, S.; Westcott, P.M.K.; Duarte, F.M.; Sankar, V.; et al. Epigenomic State Transitions Characterize Tumor Progression in Mouse Lung Adenocarcinoma. Cancer Cell 2020, 38, 212-228. [CrossRef]

32. Marjanovic, N.D.; Hofree, M.; Chan, J.E.; Canner, D.; Wu, K.; Trakala, M.; Hartmann, G.G.; Smith, O.C.; Kim, J.Y.; Evans, K.V.; et al. Emergence of a High-Plasticity Cell State during Lung Cancer Evolution. Cancer Cell 2020, 38, 229-246. [CrossRef] [PubMed]

33. Welch, D.R.; Hurst, D.R. Defining the Hallmarks of Metastasis. Cancer Res. 2019, 79, 3011-3027. [CrossRef] [PubMed]

34. Wu, Y.; Deng, J.; Rychahou, P.G.; Qiu, S.; Evers, B.M.; Zhou, B.P. Stabilization of snail by NF-kappaB is required for inflammation-induced cell migration and invasion. Cancer Cell 2009, 15, 416-428. [CrossRef]

35. Yang, M.H.; Wu, M.Z.; Chiou, S.H.; Chen, P.M.; Chang, S.Y.; Liu, C.J.; Teng, S.C.; Wu, K.J. Direct regulation of TWIST by HIF-1alpha promotes metastasis. Nat. Cell Biol. 2008, 10, 295-305. [CrossRef]

36. Jayanthi, P.; Varun, B.R.; Selvaraj, J. Epithelial-mesenchymal transition in oral squamous cell carcinoma: An insight into molecular mechanisms and clinical implications. J. Oral Maxillofac. Pathol. 2020, 24, 189. [CrossRef] [PubMed]

37. Lu, W.; Kang, Y. Epithelial-Mesenchymal Plasticity in Cancer Progression and Metastasis. Dev. Cell 2019, 49, 361-374. [CrossRef]

38. Campbell, K.; Casanova, J. A common framework for EMT and collective cell migration. Development 2016, 143, 4291-4300. [CrossRef] [PubMed]

39. Friedl, P.; Wolf, K. Tumour-cell invasion and migration: Diversity and escape mechanisms. Nat. Rev. Cancer 2003, 3, 362-374. [CrossRef]

40. Williams, E.D.; Gao, D.; Redfern, A.; Thompson, E.W. Controversies around epithelial-mesenchymal plasticity in cancer metastasis. Nat. Rev. Cancer 2019, 19, 716-732. [CrossRef] 
41. Cook, D.P.; Vanderhyden, B.C. Context specificity of the EMT transcriptional response. Nat. Commun. 2020, 11, 2142. [CrossRef]

42. De Craene, B.; Berx, G. Regulatory networks defining EMT during cancer initiation and progression. Nat. Rev. Cancer 2013, 13, 97-110. [CrossRef] [PubMed]

43. Nieto, M.A.; Huang, R.Y.; Jackson, R.A.; Thiery, J.P. Emt: 2016. Cell 2016, 166, 21-45. [CrossRef] [PubMed]

44. Pradella, D.; Naro, C.; Sette, C.; Ghigna, C. EMT and stemness: Flexible processes tuned by alternative splicing in development and cancer progression. Mol. Cancer 2017, 16, 8. [CrossRef] [PubMed]

45. Aparicio, L.A.; Abella, V.; Valladares, M.; Figueroa, A. Posttranscriptional regulation by RNA-binding proteins during epithelial-to-mesenchymal transition. Cell Mol. Life Sci. 2013, 70, 4463-4477. [CrossRef]

46. Bebee, T.W.; Cieply, B.W.; Carstens, R.P. Genome-wide activities of RNA binding proteins that regulate cellular changes in the epithelial to mesenchymal transition (EMT). Adv. Exp. Med. Biol. 2014, 825, 267-302. [CrossRef]

47. Brabletz, S.; Brabletz, T. The ZEB/miR-200 feedback loop-A motor of cellular plasticity in development and cancer? EMBO Rep. 2010, 11, 670-677. [CrossRef]

48. Dhamija, S.; Diederichs, S. From junk to master regulators of invasion: lncRNA functions in migration, EMT and metastasis. Int. J. Cancer 2016, 139, 269-280. [CrossRef]

49. Dorn, A.; Glass, M.; Neu, C.T.; Heydel, B.; Huttelmaier, S.; Gutschner, T.; Haemmerle, M. LINC00261 Is Differentially Expressed in Pancreatic Cancer Subtypes and Regulates a Pro-Epithelial Cell Identity. Cancers Basel 2020, 12, 1227. [CrossRef]

50. Lai, X.N.; Li, J.; Tang, L.B.; Chen, W.T.; Zhang, L.; Xiong, L.X. MiRNAs and LncRNAs: Dual Roles in TGF-beta Signaling-Regulated Metastasis in Lung Cancer. Int. J. Mol. Sci. 2020, 21, 1193. [CrossRef]

51. Di Stefano, B.; Luo, E.C.; Haggerty, C.; Aigner, S.; Charlton, J.; Brumbaugh, J.; Ji, F.; Rabano Jimenez, I.; Clowers, K.J.; Huebner, A.J.; et al. The RNA Helicase DDX6 Controls Cellular Plasticity by Modulating P-Body Homeostasis. Cell Stem Cell 2019, 25, 622-638. [CrossRef]

52. Hodson, D.J.; Screen, M.; Turner, M. RNA-binding proteins in hematopoiesis and hematological malignancy. Blood 2019, 133, 2365-2373. [CrossRef] [PubMed]

53. Turner, M.; Diaz-Munoz, M.D. RNA-binding proteins control gene expression and cell fate in the immune system. Nat. Immunol. 2018, 19, 120-129. [CrossRef] [PubMed]

54. Wang, S.; Jung, Y.; Hyun, J.; Friedersdorf, M.; Oh, S.H.; Kim, J.; Premont, R.T.; Keene, J.D.; Diehl, A.M. RNA Binding Proteins Control Transdifferentiation of Hepatic Stellate Cells into Myofibroblasts. Cell Physiol. Biochem. 2018, 48, 1215-1229. [CrossRef] [PubMed]

55. Gutschner, T.; Hammerle, M.; Pazaitis, N.; Bley, N.; Fiskin, E.; Uckelmann, H.; Heim, A.; Grobeta, M.; Hofmann, N.; Geffers, R.; et al. Insulin-like growth factor 2 mRNA-binding protein 1 (IGF2BP1) is an important protumorigenic factor in hepatocellular carcinoma. Hepatology 2014, 59, 1900-1911. [CrossRef] [PubMed]

56. Nachmani, D.; Gutschner, T.; Reches, A.; Diederichs, S.; Mandelboim, O. RNA-binding proteins regulate the expression of the immune activating ligand MICB. Nat. Commun. 2014, 5, 4186. [CrossRef] [PubMed]

57. Muller, S.; Bley, N.; Busch, B.; Glass, M.; Lederer, M.; Misiak, C.; Fuchs, T.; Wedler, A.; Haase, J.; Bertoldo, J.B.; et al. The oncofetal RNA-binding protein IGF2BP1 is a druggable, post-transcriptional super-enhancer of E2F-driven gene expression in cancer. Nucleic Acids Res. 2020, 48, 8576-8590. [CrossRef]

58. Muller, S.; Bley, N.; Glass, M.; Busch, B.; Rousseau, V.; Misiak, D.; Fuchs, T.; Lederer, M.; Huttelmaier, S. IGF2BP1 enhances an aggressive tumor cell phenotype by impairing miRNA-directed downregulation of oncogenic factors. Nucleic Acids Res. 2018, 46, 6285-6303. [CrossRef]

59. Gerstberger, S.; Hafner, M.; Tuschl, T. A census of human RNA-binding proteins. Nat. Rev. Genet. 2014, 15, 829-845. [CrossRef]

60. Baltz, A.G.; Munschauer, M.; Schwanhausser, B.; Vasile, A.; Murakawa, Y.; Schueler, M.; Youngs, N.; Penfold-Brown, D.; Drew, K.; Milek, M.; et al. The mRNA-bound proteome and its global occupancy profile on protein-coding transcripts. Mol. Cell 2012, 46, 674-690. [CrossRef]

61. Castello, A.; Fischer, B.; Eichelbaum, K.; Horos, R.; Beckmann, B.M.; Strein, C.; Davey, N.E.; Humphreys, D.T.; Preiss, T.; Steinmetz, L.M.; et al. Insights into RNA biology from an atlas of mammalian mRNA-binding proteins. Cell 2012, 149, 1393-1406. [CrossRef] 
62. Kwon, S.C.; Yi, H.; Eichelbaum, K.; Fohr, S.; Fischer, B.; You, K.T.; Castello, A.; Krijgsveld, J.; Hentze, M.W.; Kim, V.N. The RNA-binding protein repertoire of embryonic stem cells. Nat. Struct. Mol. Biol. 2013, 20, 1122-1130. [CrossRef] [PubMed]

63. Hentze, M.W.; Castello, A.; Schwarzl, T.; Preiss, T. A brave new world of RNA-binding proteins. Nat. Rev. Mol. Cell Biol. 2018, 19, 327-341. [CrossRef] [PubMed]

64. Trendel, J.; Schwarzl, T.; Horos, R.; Prakash, A.; Bateman, A.; Hentze, M.W.; Krijgsveld, J. The Human RNA-Binding Proteome and Its Dynamics during Translational Arrest. Cell 2019, 176, 391-403. [CrossRef]

65. Lunde, B.M.; Moore, C.; Varani, G. RNA-binding proteins: Modular design for efficient function. Nat. Rev. Mol. Cell Biol. 2007, 8, 479-490. [CrossRef] [PubMed]

66. Jarvelin, A.I.; Noerenberg, M.; Davis, I.; Castello, A. The new (dis)order in RNA regulation. Cell Commun. Signal. 2016, 14, 9. [CrossRef]

67. Castello, A.; Hentze, M.W.; Preiss, T. Metabolic Enzymes Enjoying New Partnerships as RNA-Binding Proteins. Trends Endocrinol. Metab. 2015, 26, 746-757. [CrossRef]

68. Brannan, K.W.; Jin, W.; Huelga, S.C.; Banks, C.A.; Gilmore, J.M.; Florens, L.; Washburn, M.P.; Van Nostrand, E.L.; Pratt, G.A.; Schwinn, M.K.; et al. SONAR Discovers RNA-Binding Proteins from Analysis of Large-Scale Protein-Protein Interactomes. Mol. Cell 2016, 64, 282-293. [CrossRef]

69. Nicholson, C.O.; Friedersdorf, M.; Keene, J.D. Quantifying RNA binding sites transcriptome-wide using DO-RIP-seq. RNA 2017, 23, 32-46. [CrossRef]

70. Hammerle, M.; Gutschner, T.; Uckelmann, H.; Ozgur, S.; Fiskin, E.; Gross, M.; Skawran, B.; Geffers, R.; Longerich, T.; Breuhahn, K.; et al. Posttranscriptional destabilization of the liver-specific long noncoding RNA HULC by the IGF2 mRNA-binding protein 1 (IGF2BP1). Hepatology 2013, 58, 1703-1712. [CrossRef]

71. Hu, W.L.; Jin, L.; Xu, A.; Wang, Y.F.; Thorne, R.F.; Zhang, X.D.; Wu, M. GUARDIN is a p53-responsive long non-coding RNA that is essential for genomic stability. Nat. Cell Biol. 2018, 20, 492-502. [CrossRef]

72. Jonas, K.; Calin, G.A.; Pichler, M. RNA-Binding Proteins as Important Regulators of Long Non-Coding RNAs in Cancer. Int. J. Mol. Sci. 2020, 21, 2969. [CrossRef] [PubMed]

73. Li, Z.; Hou, P.; Fan, D.; Dong, M.; Ma, M.; Li, H.; Yao, R.; Li, Y.; Wang, G.; Geng, P.; et al. The degradation of EZH2 mediated by lncRNA ANCR attenuated the invasion and metastasis of breast cancer. Cell Death Differ. 2017, 24, 59-71. [CrossRef] [PubMed]

74. Schmitt, A.M.; Garcia, J.T.; Hung, T.; Flynn, R.A.; Shen, Y.; Qu, K.; Payumo, A.Y.; Peres-da-Silva, A.; Broz, D.K.; Baum, R.; et al. An inducible long noncoding RNA amplifies DNA damage signaling. Nat. Genet. 2016, 48, 1370-1376. [CrossRef] [PubMed]

75. Gupta, R.A.; Shah, N.; Wang, K.C.; Kim, J.; Horlings, H.M.; Wong, D.J.; Tsai, M.C.; Hung, T.; Argani, P.; Rinn, J.L.; et al. Long non-coding RNA HOTAIR reprograms chromatin state to promote cancer metastasis. Nature 2010, 464, 1071-1076. [CrossRef]

76. Gutschner, T.; Diederichs, S. The hallmarks of cancer: A long non-coding RNA point of view. RNA Biol. 2012, 9, 703-719. [CrossRef]

77. Rinn, J.L.; Kertesz, M.; Wang, J.K.; Squazzo, S.L.; Xu, X.; Brugmann, S.A.; Goodnough, L.H.; Helms, J.A.; Farnham, P.J.; Segal, E.; et al. Functional demarcation of active and silent chromatin domains in human HOX loci by noncoding RNAs. Cell 2007, 129, 1311-1323. [CrossRef]

78. Nussbacher, J.K.; Yeo, G.W. Systematic Discovery of RNA Binding Proteins that Regulate MicroRNA Levels. Mol. Cell 2018, 69, 1005-1016. [CrossRef]

79. Treiber, T.; Treiber, N.; Meister, G. Identification of microRNA Precursor-Associated Proteins. Methods Mol. Biol. 2018, 1823, 103-114. [CrossRef]

80. Busch, B.; Bley, N.; Muller, S.; Glass, M.; Misiak, D.; Lederer, M.; Vetter, M.; Strauss, H.G.; Thomssen, C.; Huttelmaier, S. The oncogenic triangle of HMGA2, LIN28B and IGF2BP1 antagonizes tumor-suppressive actions of the let-7 family. Nucleic Acids Res. 2016, 44, 3845-3864. [CrossRef]

81. Jing, Q.; Huang, S.; Guth, S.; Zarubin, T.; Motoyama, A.; Chen, J.; Di Padova, F.; Lin, S.C.; Gram, H.; Han, J. Involvement of microRNA in AU-rich element-mediated mRNA instability. Cell 2005, 120, 623-634. [CrossRef]

82. Kim, H.H.; Kuwano, Y.; Srikantan, S.; Lee, E.K.; Martindale, J.L.; Gorospe, M. HuR recruits let-7/RISC to repress c-Myc expression. Genes Dev. 2009, 23, 1743-1748. [CrossRef] [PubMed] 
83. Shiber, A.; Doring, K.; Friedrich, U.; Klann, K.; Merker, D.; Zedan, M.; Tippmann, F.; Kramer, G.; Bukau, B. Cotranslational assembly of protein complexes in eukaryotes revealed by ribosome profiling. Nature 2018, 561, 268-272. [CrossRef] [PubMed]

84. Mayr, C. Protein complexes assemble as they are being made. Nature 2018, 561, 186-187. [CrossRef] [PubMed]

85. Berkovits, B.D.; Mayr, C. Alternative 3' UTRs act as scaffolds to regulate membrane protein localization. Nature 2015, 522, 363-367. [CrossRef] [PubMed]

86. Lee, S.H.; Mayr, C. Gain of Additional BIRC3 Protein Functions through 3'-UTR-Mediated Protein Complex Formation. Mol. Cell 2019, 74, 701-712. [CrossRef]

87. Ma, W.; Mayr, C. A Membraneless Organelle Associated with the Endoplasmic Reticulum Enables 3'UTR-Mediated Protein-Protein Interactions. Cell 2018, 175, 1492-1506. [CrossRef]

88. Mayr, C. What Are 3' UTRs Doing? Cold Spring Harb. Perspect. Biol. 2019, 11. [CrossRef]

89. Bell, J.L.; Hagemann, S.; Holien, J.K.; Liu, T.; Nagy, Z.; Schulte, J.H.; Misiak, D.; Huttelmaier, S. Identification of RNA-Binding Proteins as Targetable Putative Oncogenes in Neuroblastoma. Int. J. Mol. Sci. 2020, 21, 5098. [CrossRef]

90. Conlon, E.G.; Manley, J.L. RNA-binding proteins in neurodegeneration: Mechanisms in aggregate. Genes Dev. 2017, 31, 1509-1528. [CrossRef]

91. Glass, M.; Michl, P.; Huttelmaier, A.S. RNA Binding Proteins as Drivers and Therapeutic Target Candidates in Pancreatic Ductal Adenocarcinoma. Int. J. Mol. Sci. 2020, 21, 4190. [CrossRef]

92. Kechavarzi, B.; Janga, S.C. Dissecting the expression landscape of RNA-binding proteins in human cancers. Genome Biol. 2014, 15, R14. [CrossRef] [PubMed]

93. Libner, C.D.; Salapa, H.E.; Levin, M.C. The Potential Contribution of Dysfunctional RNA-Binding Proteins to the Pathogenesis of Neurodegeneration in Multiple Sclerosis and Relevant Models. Int. J. Mol. Sci 2020, 21, 4571. [CrossRef] [PubMed]

94. Salem, E.S.B.; Vonberg, A.D.; Borra, V.J.; Gill, R.K.; Nakamura, T. RNAs and RNA-Binding Proteins in Immuno-Metabolic Homeostasis and Diseases. Front. Cardiovasc. Med. 2019, 6, 106. [CrossRef] [PubMed]

95. Schuschel, K.; Helwig, M.; Huttelmaier, S.; Heckl, D.; Klusmann, J.H.; Hoell, J.I. RNA-Binding Proteins in Acute Leukemias. Int. J. Mol. Sci. 2020, 21, 3409. [CrossRef] [PubMed]

96. Zhang, H.; Brown, R.D.; Stenmark, K.R.; Hu, C.J. RNA-Binding Proteins in Pulmonary Hypertension. Int. J. Mol. Sci. 2020, 21, 3757. [CrossRef]

97. Fritzell, K.; Xu, L.D.; Lagergren, J.; Ohman, M. ADARs and editing: The role of A-to-I RNA modification in cancer progression. Semin. Cell Dev. Biol. 2018, 79, 123-130. [CrossRef]

98. Han, L.; Diao, L.; Yu, S.; Xu, X.; Li, J.; Zhang, R.; Yang, Y.; Werner, H.M.J.; Eterovic, A.K.; Yuan, Y.; et al. The Genomic Landscape and Clinical Relevance of A-to-I RNA Editing in Human Cancers. Cancer Cell 2015, 28, 515-528. [CrossRef]

99. Li, L.; Song, Y.; Shi, X.; Liu, J.; Xiong, S.; Chen, W.; Fu, Q.; Huang, Z.; Gu, N.; Zhang, R. The landscape of miRNA editing in animals and its impact on miRNA biogenesis and targeting. Genome Res. 2018, 28, 132-143. [CrossRef]

100. Nemlich, Y.; Greenberg, E.; Ortenberg, R.; Besser, M.J.; Barshack, I.; Jacob-Hirsch, J.; Jacoby, E.; Eyal, E.; Rivkin, L.; Prieto, V.G.; et al. MicroRNA-mediated loss of ADAR1 in metastatic melanoma promotes tumor growth. J. Clin. Investig. 2013, 123, 2703-2718. [CrossRef]

101. Ota, H.; Sakurai, M.; Gupta, R.; Valente, L.; Wulff, B.E.; Ariyoshi, K.; Iizasa, H.; Davuluri, R.V.; Nishikura, K. ADAR1 forms a complex with Dicer to promote microRNA processing and RNA-induced gene silencing. Cell 2013, 153, 575-589. [CrossRef]

102. Liu, X.; Fu, Y.; Huang, J.; Wu, M.; Zhang, Z.; Xu, R.; Zhang, P.; Zhao, S.; Liu, L.; Jiang, H. ADAR1 promotes the epithelial-to-mesenchymal transition and stem-like cell phenotype of oral cancer by facilitating oncogenic microRNA maturation. J. Exp. Clin. Cancer Res. 2019, 38, 315. [CrossRef] [PubMed]

103. Caponio, V.C.A.; Troiano, G.; Botti, G.; Pedicillo, M.C.; Lo Russo, L.; Mastrangelo, F.; Ciavarella, D.; Losito, N.S.; Aquino, G.; Nocini, R.; et al. Overexpression of ADAR1 into the cytoplasm correlates with a better prognosis of patients with oral squamous cells carcinoma. J. Oral Pathol. Med. 2019, 48, 108-114. [CrossRef] [PubMed]

104. Ariumi, Y. Multiple functions of DDX3 RNA helicase in gene regulation, tumorigenesis, and viral infection. Front. Genet. 2014, 5, 423. [CrossRef] 
105. Kukhanova, M.K.; Karpenko, I.L.; Ivanov, A.V. DEAD-box RNA Helicase DDX3: Functional Properties and Development of DDX3 Inhibitors as Antiviral and Anticancer Drugs. Mol. Basel Switz. 2020, 25, 1015. [CrossRef]

106. Chen, H.H.; Yu, H.I.; Tarn, W.Y. DDX3 Modulates Neurite Development via Translationally Activating an RNA Regulon Involved in Rac1 Activation. J. Neurosci. 2016, 36, 9792-9804. [CrossRef]

107. Chen, H.H.; Yu, H.I.; Yang, M.H.; Tarn, W.Y. DDX3 Activates CBC-eIF3-Mediated Translation of uORF-Containing Oncogenic mRNAs to Promote Metastasis in HNSCC. Cancer Res. 2018, 78, 4512-4523. [CrossRef]

108. Soto-Rifo, R.; Rubilar, P.S.; Limousin, T.; de Breyne, S.; Decimo, D.; Ohlmann, T. DEAD-box protein DDX3 associates with eIF4F to promote translation of selected mRNAs. EMBO J. 2012, 31, 3745-3756. [CrossRef]

109. Lee, C.S.; Dias, A.P.; Jedrychowski, M.; Patel, A.H.; Hsu, J.L.; Reed, R. Human DDX3 functions in translation and interacts with the translation initiation factor eIF3. Nucleic Acids Res. 2008, 36, 4708-4718. [CrossRef]

110. Shih, J.W.; Tsai, T.Y.; Chao, C.H.; Wu Lee, Y.H. Candidate tumor suppressor DDX3 RNA helicase specifically represses cap-dependent translation by acting as an eIF4E inhibitory protein. Oncogene 2008, 27, 700-714. [CrossRef]

111. Bol, G.M.; Xie, M.; Raman, V. DDX3, a potential target for cancer treatment. Mol. Cancer 2015, $14,188$. [CrossRef]

112. Chen, H.H.; Yu, H.I.; Cho, W.C.; Tarn, W.Y. DDX3 modulates cell adhesion and motility and cancer cell metastasis via Rac1-mediated signaling pathway. Oncogene 2015, 34, 2790-2800. [CrossRef] [PubMed]

113. Good, P.J. A conserved family of elav-like genes in vertebrates. Proc. Natl. Acad. Sci. USA 1995, 92, 4557-4561. [CrossRef] [PubMed]

114. Grammatikakis, I.; Abdelmohsen, K.; Gorospe, M. Posttranslational control of HuR function. Wiley Interdiscip. Rev. RNA 2017, 8. [CrossRef] [PubMed]

115. Schultz, C.W.; Preet, R.; Dhir, T.; Dixon, D.A.; Brody, J.R. Understanding and targeting the disease-related RNA binding protein human antigen $\mathrm{R}(\mathrm{HuR})$. Wiley Interdiscip. Rev. RNA 2020, 11, e1581. [CrossRef] [PubMed]

116. Chang, S.H.; Elemento, O.; Zhang, J.; Zhuang, Z.W.; Simons, M.; Hla, T. ELAVL1 regulates alternative splicing of eIF4E transporter to promote postnatal angiogenesis. Proc. Natl. Acad. Sci. USA 2014, 111, 18309-18314. [CrossRef]

117. Dutertre, M.; Chakrama, F.Z.; Combe, E.; Desmet, F.O.; Mortada, H.; Espinoza, M.P.; Gratadou, L.; Auboeuf, D. A recently evolved class of alternative $3^{\prime}$-terminal exons involved in cell cycle regulation by topoisomerase inhibitors. Nat. Commun. 2014, 5, 3395. [CrossRef]

118. Lebedeva, S.; Jens, M.; Theil, K.; Schwanhausser, B.; Selbach, M.; Landthaler, M.; Rajewsky, N. Transcriptome-wide analysis of regulatory interactions of the RNA-binding protein HuR. Mol. Cell 2011, 43, 340-352. [CrossRef]

119. Ripin, N.; Boudet, J.; Duszczyk, M.M.; Hinniger, A.; Faller, M.; Krepl, M.; Gadi, A.; Schneider, R.J.; Sponer, J.; Meisner-Kober, N.C.; et al. Molecular basis for AU-rich element recognition and dimerization by the HuR C-terminal RRM. Proc. Natl. Acad. Sci. USA 2019, 116, 2935-2944. [CrossRef]

120. Fan, X.C.; Steitz, J.A. Overexpression of HuR, a nuclear-cytoplasmic shuttling protein, increases the in vivo stability of ARE-containing mRNAs. EMBO J. 1998, 17, 3448-3460. [CrossRef]

121. Dixon, D.A.; Tolley, N.D.; King, P.H.; Nabors, L.B.; McIntyre, T.M.; Zimmerman, G.A.; Prescott, S.M. Altered expression of the mRNA stability factor HuR promotes cyclooxygenase-2 expression in colon cancer cells. J. Clin. Investig. 2001, 108, 1657-1665. [CrossRef]

122. Nabors, L.B.; Gillespie, G.Y.; Harkins, L.; King, P.H. HuR, a RNA stability factor, is expressed in malignant brain tumors and binds to adenine- and uridine-rich elements within the $3^{\prime}$ untranslated regions of cytokine and angiogenic factor mRNAs. Cancer Res. 2001, 61, 2154-2161. [PubMed]

123. Srikantan, S.; Gorospe, M. HuR function in disease. Front. Biosci. Landmark Ed. 2012, 17, 189-205. [CrossRef] [PubMed]

124. Peng, W.; Furuuchi, N.; Aslanukova, L.; Huang, Y.H.; Brown, S.Z.; Jiang, W.; Addya, S.; Vishwakarma, V.; Peters, E.; Brody, J.R.; et al. Elevated HuR in Pancreas Promotes a Pancreatitis-Like Inflammatory Microenvironment That Facilitates Tumor Development. Mol. Cell Biol. 2018, 38. [CrossRef] [PubMed] 
125. Hasegawa, H.; Kakuguchi, W.; Kuroshima, T.; Kitamura, T.; Tanaka, S.; Kitagawa, Y.; Totsuka, Y.; Shindoh, M.; Higashino, F. HuR is exported to the cytoplasm in oral cancer cells in a different manner from that of normal cells. Br. J. Cancer 2009, 100, 1943-1948. [CrossRef] [PubMed]

126. Kakuguchi, W.; Kitamura, T.; Kuroshima, T.; Ishikawa, M.; Kitagawa, Y.; Totsuka, Y.; Shindoh, M.; Higashino, F. HuR knockdown changes the oncogenic potential of oral cancer cells. Mol. Cancer Res. 2010, 8, 520-528. [CrossRef]

127. Cha, J.D.; Li, S.; Cha, I.H. Association between expression of embryonic lethal abnormal vision-like protein HuR and cyclooxygenase-2 in oral squamous cell carcinoma. Head Neck 2011, 33, 627-637. [CrossRef]

128. Goradel, N.H.; Najafi, M.; Salehi, E.; Farhood, B.; Mortezaee, K. Cyclooxygenase-2 in cancer: A review. J. Cell Physiol. 2019, 234, 5683-5699. [CrossRef]

129. Cherry, S.; Lynch, K.W. Alternative splicing and cancer: Insights, opportunities, and challenges from an expanding view of the transcriptome. Genes Dev. 2020, 34, 1005-1016. [CrossRef]

130. Nilsen, T.W.; Graveley, B.R. Expansion of the eukaryotic proteome by alternative splicing. Nature 2010, 463, 457-463. [CrossRef]

131. Ule, J.; Blencowe, B.J. Alternative Splicing Regulatory Networks: Functions, Mechanisms, and Evolution. Mol. Cell 2019, 76, 329-345. [CrossRef]

132. Baralle, F.E.; Giudice, J. Alternative splicing as a regulator of development and tissue identity. Nat. Rev. Mol. Cell Biol. 2017, 18, 437-451. [CrossRef]

133. Fiszbein, A.; Kornblihtt, A.R. Alternative splicing switches: Important players in cell differentiation. Bioessays 2017, 39. [CrossRef]

134. Warzecha, C.C.; Jiang, P.; Amirikian, K.; Dittmar, K.A.; Lu, H.; Shen, S.; Guo, W.; Xing, Y.; Carstens, R.P. An ESRP-regulated splicing programme is abrogated during the epithelial-mesenchymal transition. EMBO J. 2010, 29, 3286-3300. [CrossRef]

135. Warzecha, C.C.; Sato, T.K.; Nabet, B.; Hogenesch, J.B.; Carstens, R.P. ESRP1 and ESRP2 are epithelial cell-type-specific regulators of FGFR2 splicing. Mol. Cell 2009, 33, 591-601. [CrossRef]

136. Warzecha, C.C.; Shen, S.; Xing, Y.; Carstens, R.P. The epithelial splicing factors ESRP1 and ESRP2 positively and negatively regulate diverse types of alternative splicing events. RNA Biol. 2009, 6, 546-562. [CrossRef]

137. Shirakihara, T.; Horiguchi, K.; Miyazawa, K.; Ehata, S.; Shibata, T.; Morita, I.; Miyazono, K.; Saitoh, M. TGF-beta regulates isoform switching of FGF receptors and epithelial-mesenchymal transition. EMBO J. 2011, 30, 783-795. [CrossRef]

138. Horiguchi, K.; Sakamoto, K.; Koinuma, D.; Semba, K.; Inoue, A.; Inoue, S.; Fujii, H.; Yamaguchi, A.; Miyazawa, K.; Miyazono, K.; et al. TGF-beta drives epithelial-mesenchymal transition through deltaEF1-mediated downregulation of ESRP. Oncogene 2012, 31, 3190-3201. [CrossRef]

139. Leontieva, O.V.; Ionov, Y. RNA-binding motif protein $35 \mathrm{~A}$ is a novel tumor suppressor for colorectal cancer. Cell Cycle 2009, 8, 490-497. [CrossRef]

140. Yae, T.; Tsuchihashi, K.; Ishimoto, T.; Motohara, T.; Yoshikawa, M.; Yoshida, G.J.; Wada, T.; Masuko, T.; Mogushi, K.; Tanaka, H.; et al. Alternative splicing of CD44 mRNA by ESRP1 enhances lung colonization of metastatic cancer cell. Nat. Commun. 2012, 3, 883. [CrossRef]

141. Ishii, H.; Saitoh, M.; Sakamoto, K.; Kondo, T.; Katoh, R.; Tanaka, S.; Motizuki, M.; Masuyama, K.; Miyazawa, K. Epithelial splicing regulatory proteins 1 (ESRP1) and 2 (ESRP2) suppress cancer cell motility via different mechanisms. J. Biol. Chem. 2014, 289, 27386-27399. [CrossRef]

142. Zhao, W.; Cui, Y.; Liu, L.; Qi, X.; Liu, J.; Ma, S.; Hu, X.; Zhang, Z.; Wang, Y.; Li, H.; et al. Splicing factor derived circular RNA circUHRF1 accelerates oral squamous cell carcinoma tumorigenesis via feedback loop. Cell Death Differ. 2020, 27, 919-933. [CrossRef] [PubMed]

143. Bell, J.L.; Wachter, K.; Muhleck, B.; Pazaitis, N.; Kohn, M.; Lederer, M.; Huttelmaier, S. Insulin-like growth factor 2 mRNA-binding proteins (IGF2BPs): Post-transcriptional drivers of cancer progression? Cell Mol. Life Sci. 2013, 70, 2657-2675. [CrossRef]

144. Wachter, K.; Kohn, M.; Stohr, N.; Huttelmaier, S. Subcellular localization and RNP formation of IGF2BPs (IGF2 mRNA-binding proteins) is modulated by distinct RNA-binding domains. Biol. Chem. 2013, 394, 1077-1090. [CrossRef] [PubMed] 
145. Hafner, M.; Landthaler, M.; Burger, L.; Khorshid, M.; Hausser, J.; Berninger, P.; Rothballer, A.; Ascano, M., Jr.; Jungkamp, A.C.; Munschauer, M.; et al. Transcriptome-wide identification of RNA-binding protein and microRNA target sites by PAR-CLIP. Cell 2010, 141, 129-141. [CrossRef]

146. Lederer, M.; Bley, N.; Schleifer, C.; Huttelmaier, S. The role of the oncofetal IGF2 mRNA-binding protein 3 (IGF2BP3) in cancer. Semin. Cancer Biol. 2014, 29, 3-12. [CrossRef]

147. Clauditz, T.S.; Wang, C.J.; Gontarewicz, A.; Blessmann, M.; Tennstedt, P.; Borgmann, K.; Tribius, S.; Sauter, G.; Dalchow, C.; Knecht, R.; et al. Expression of insulin-like growth factor II mRNA-binding protein 3 in squamous cell carcinomas of the head and neck. J. Oral Pathol. Med. 2013, 42, 125-132. [CrossRef]

148. Hwang, Y.S.; Xianglan, Z.; Park, K.K.; Chung, W.Y. Functional invadopodia formation through stabilization of the PDPN transcript by IMP-3 and cancer-stromal crosstalk for PDPN expression. Carcinogenesis 2012, 33, 2135-2146. [CrossRef]

149. Kim, K.Y.; Cha, I.H. A novel algorithm for lymph node status prediction of oral cancer before surgery. Oral Oncol. 2011, 47, 1069-1073. [CrossRef]

150. Kim, K.Y.; Cha, I.H. Risk stratification of oral cancer patients using a combined prognostic factor including lymph node density and biomarker. J. Cancer Res. Clin. Oncol. 2012, 138, 483-490. [CrossRef]

151. Kim, K.Y.; Li, S.; Cha, J.D.; Zhang, X.; Cha, I.H. Significance of molecular markers in survival prediction of oral squamous cell carcinoma. Head Neck 2012, 34, 929-936. [CrossRef]

152. Li, S.; Cha, J.; Kim, J.; Kim, K.Y.; Kim, H.J.; Nam, W.; Cha, I.H. Insulin-like growth factor II mRNA-binding protein 3: A novel prognostic biomarker for oral squamous cell carcinoma. Head Neck 2011, 33, 368-374. [CrossRef] [PubMed]

153. Lin, C.Y.; Chen, S.T.; Jeng, Y.M.; Yeh, C.C.; Chou, H.Y.; Deng, Y.T.; Chang, C.C.; Kuo, M.Y. Insulin-like growth factor II mRNA-binding protein 3 expression promotes tumor formation and invasion and predicts poor prognosis in oral squamous cell carcinoma. J. Oral Pathol. Med. 2011, 40, 699-705. [CrossRef] [PubMed]

154. Hwang, Y.S.; Park, K.K.; Cha, I.H.; Kim, J.; Chung, W.Y. Role of insulin-like growth factor-II mRNA-binding protein-3 in invadopodia formation and the growth of oral squamous cell carcinoma in athymic nude mice. Head Neck 2012, 34, 1329-1339. [CrossRef] [PubMed]

155. Hwang, Y.S.; Ahn, S.Y.; Moon, S.; Zheng, Z.; Cha, I.H.; Kim, J.; Zhang, X. Insulin-like growth factor-II mRNA binding protein-3 and podoplanin expression are associated with bone invasion and prognosis in oral squamous cell carcinoma. Arch. Oral Biol. 2016, 69, 25-32. [CrossRef]

156. Tarsitano, A.; Asioli, S.; Morandi, L.; Monti, V.; Righi, A.; Labate, A.M.M.; Nardi, E.; Foschini, M.P.; Marchetti, C. Laminin-5 and insulin-like growth factor-II mRNA binding protein-3 (IMP3) expression in preoperative biopsy specimens from oral cancer patients: Their role in neural spread risk and survival stratification. J. Cranio-Maxillofac. Surg. 2016, 44, 1896-1902. [CrossRef]

157. Zhang, X.; Jung, I.H.; Hwang, Y.S. EGF enhances low-invasive cancer cell invasion by promoting IMP-3 expression. Tumour Biol. 2016, 37, 2555-2563. [CrossRef]

158. Moss, E.G.; Lee, R.C.; Ambros, V. The cold shock domain protein LIN-28 controls developmental timing in C. elegans and is regulated by the lin-4 RNA. Cell 1997, 88, 637-646. [CrossRef]

159. Li, M.; Chen, H.; Wu, T. LIN28: A cancer stem cell promoter for immunotherapy in head and neck squamous cell carcinoma. Oral Oncol. 2019, 98, 92-95. [CrossRef]

160. Piskounova, E.; Polytarchou, C.; Thornton, J.E.; LaPierre, R.J.; Pothoulakis, C.; Hagan, J.P.; Iliopoulos, D.; Gregory, R.I. Lin28A and Lin28B inhibit let-7 microRNA biogenesis by distinct mechanisms. Cell 2011, 147, 1066-1079. [CrossRef]

161. Wu, T.; Jia, J.; Xiong, X.; He, H.; Bu, L.; Zhao, Z.; Huang, C.; Zhang, W. Increased expression of Lin28B associates with poor prognosis in patients with oral squamous cell carcinoma. PLoS ONE 2013, 8, e83869. [CrossRef]

162. Wang, D.; Zhu, Y.; Wang, Y.; Li, Z.; Yuan, C.; Zhang, W.; Yuan, H.; Ye, J.; Yang, J.; Jiang, H.; et al. The pluripotency factor LIN28B is involved in oral carcinogenesis and associates with tumor aggressiveness and unfavorable prognosis. Cancer Cell Int. 2015, 15, 99. [CrossRef] [PubMed]

163. Lin, W.T.; Shieh, T.M.; Yang, L.C.; Wang, T.Y.; Chou, M.Y.; Yu, C.C. Elevated Lin28B expression is correlated with lymph node metastasis in oral squamous cell carcinomas. J. Oral Pathol. Med. 2015, 44, 823-830. [CrossRef] [PubMed] 
164. Chien, C.S.; Wang, M.L.; Chu, P.Y.; Chang, Y.L.; Liu, W.H.; Yu, C.C.; Lan, Y.T.; Huang, P.I.; Lee, Y.Y.; Chen, Y.W.; et al. Lin28B/Let-7 Regulates Expression of Oct4 and Sox2 and Reprograms Oral Squamous Cell Carcinoma Cells to a Stem-like State. Cancer Res. 2015, 75, 2553-2565. [CrossRef]

165. Huang, H.; Weng, H.; Chen, J. m(6)A Modification in Coding and Non-coding RNAs: Roles and Therapeutic Implications in Cancer. Cancer Cell 2020, 37, 270-288. [CrossRef]

166. Jacob, R.; Zander, S.; Gutschner, T. The Dark Side of the Epitranscriptome: Chemical Modifications in Long Non-Coding RNAs. Int. J. Mol. Sci. 2017, 18, 2387. [CrossRef] [PubMed]

167. Wang, X.; He, C. Dynamic RNA modifications in posttranscriptional regulation. Mol. Cell 2014, 56, 5-12. [CrossRef]

168. Barbieri, I.; Kouzarides, T. Role of RNA modifications in cancer. Nat. Rev. Cancer 2020, 20, 303-322. [CrossRef]

169. Chen, J.; Fang, X.; Zhong, P.; Song, Z.; Hu, X. N6-methyladenosine modifications: Interactions with novel RNA-binding proteins and roles in signal transduction. RNA Biol. 2019, 16, 991-1000. [CrossRef]

170. Zaccara, S.; Ries, R.J.; Jaffrey, S.R. Reading, writing and erasing mRNA methylation. Nat. Rev. Mol. Cell Biol. 2019, 20, 608-624. [CrossRef]

171. Sledz, P.; Jinek, M. Structural insights into the molecular mechanism of the m(6)A writer complex. eLife 2016, 5, e18434. [CrossRef]

172. Wang, P.; Doxtader, K.A.; Nam, Y. Structural Basis for Cooperative Function of Mettl3 and Mettl14 Methyltransferases. Mol. Cell 2016, 63, 306-317. [CrossRef] [PubMed]

173. Wang, X.; Feng, J.; Xue, Y.; Guan, Z.; Zhang, D.; Liu, Z.; Gong, Z.; Wang, Q.; Huang, J.; Tang, C.; et al. Structural basis of N(6)-adenosine methylation by the METTL3-METTL14 complex. Nature 2016, 534, 575-578. [CrossRef] [PubMed]

174. Geula, S.; Moshitch-Moshkovitz, S.; Dominissini, D.; Mansour, A.A.; Kol, N.; Salmon-Divon, M.; Hershkovitz, V.; Peer, E.; Mor, N.; Manor, Y.S.; et al. Stem cells. m6A mRNA methylation facilitates resolution of naive pluripotency toward differentiation. Science 2015, 347, 1002-1006. [CrossRef] [PubMed]

175. Huang, G.Z.; Wu, Q.Q.; Zheng, Z.N.; Shao, T.R.; Chen, Y.C.; Zeng, W.S.; Lv, X.Z. M6A-related bioinformatics analysis reveals that HNRNPC facilitates progression of OSCC via EMT. Aging Albany N. Y. 2020, 12, 11667-11684. [CrossRef]

176. Liu, L.; Wu, Y.; Li, Q.; Liang, J.; He, Q.; Zhao, L.; Chen, J.; Cheng, M.; Huang, Z.; Ren, H.; et al. METTL3 Promotes Tumorigenesis and Metastasis through BMI1 m(6)A Methylation in Oral Squamous Cell Carcinoma. Mol. Ther. 2020, in press. [CrossRef]

177. Zhao, W.; Cui, Y.; Liu, L.; Ma, X.; Qi, X.; Wang, Y.; Liu, Z.; Ma, S.; Liu, J.; Wu, J. METTL3 Facilitates Oral Squamous Cell Carcinoma Tumorigenesis by Enhancing c-Myc Stability via YTHDF1-Mediated m(6)A Modification. Mol. Ther. Nucleic Acids 2020, 20,1-12. [CrossRef]

178. Chen, D.; Wu, M.; Li, Y.; Chang, I.; Yuan, Q.; Ekimyan-Salvo, M.; Deng, P.; Yu, B.; Yu, Y.; Dong, J.; et al. Targeting BMI1(+) Cancer Stem Cells Overcomes Chemoresistance and Inhibits Metastases in Squamous Cell Carcinoma. Cell Stem Cell 2017, 20, 621-634. [CrossRef]

179. Huang, H.; Weng, H.; Sun, W.; Qin, X.; Shi, H.; Wu, H.; Zhao, B.S.; Mesquita, A.; Liu, C.; Yuan, C.L.; et al. Recognition of RNA N(6)-methyladenosine by IGF2BP proteins enhances mRNA stability and translation. Nat. Cell Biol. 2018, 20, 285-295. [CrossRef]

180. Sasahira, T.; Kurihara, M.; Yamamoto, K.; Ueda, N.; Nakashima, C.; Matsushima, S.; Bhawal, U.K.; Kirita, T.; Kuniyasu, H. HuD promotes progression of oral squamous cell carcinoma. Pathobiology 2014, 81, $206-214$. [CrossRef]

181. Jia, R.; Zhang, S.; Liu, M.; Zhang, Y.; Liu, Y.; Fan, M.; Guo, J. HnRNP L is important for the expression of oncogene SRSF3 and oncogenic potential of oral squamous cell carcinoma cells. Sci. Rep. 2016, 6, 35976. [CrossRef]

182. Ravindran, G.; Devaraj, H. Prognostic significance of neural stem cell markers, Nestin and Musashi-1, in oral squamous cell carcinoma: Expression pattern of Nestin in the precancerous stages of oral squamous epithelium. Clin. Oral Investig. 2015, 19, 1251-1260. [CrossRef] [PubMed]

183. Wang, C.F.; Zhang, H.C.; Feng, X.M.; Song, X.M.; Wu, Y.N. Knockdown of MSI1 inhibits the proliferation of human oral squamous cell carcinoma by inactivating STAT3 signaling. Int. J. Mol. Med. 2019, 44, 115-124. [CrossRef] [PubMed] 
184. Lu, W.; Feng, F.; Xu, J.; Lu, X.; Wang, S.; Wang, L.; Lu, H.; Wei, M.; Yang, G.; Wang, L.; et al. QKI impairs self-renewal and tumorigenicity of oral cancer cells via repression of SOX2. Cancer Biol. Ther. 2014, 15, 1174-1184. [CrossRef] [PubMed]

185. Kim, E.J.; Kim, J.S.; Lee, S.; Lee, H.; Yoon, J.S.; Hong, J.H.; Chun, S.H.; Sun, S.; Won, H.S.; Hong, S.A.; et al. QKI, a miR-200 target gene, suppresses epithelial-to-mesenchymal transition and tumor growth. Int. J. Cancer 2019, 145, 1585-1595. [CrossRef] [PubMed]

186. Liu, P.; Guo, Z.; Yin, Y.; Jia, J.; Guo, J.; Jia, R. Expression of SRSF3 is Correlated with Carcinogenesis and Progression of Oral Squamous Cell Carcinoma. Int. J. Med. Sci. 2016, 13, 533-539. [CrossRef]

187. Sommer, G.; Rossa, C.; Chi, A.C.; Neville, B.W.; Heise, T. Implication of RNA-binding protein La in proliferation, migration and invasion of lymph node-metastasized hypopharyngeal SCC cells. PLoS ONE 2011, 6, e25402. [CrossRef]

188. Zhu, S.; Rooney, S.; Michlewski, G. RNA-Targeted Therapies and High-Throughput Screening Methods. Int. J. Mol. Sci. 2020, 21, 2996. [CrossRef]

189. Mohibi, S.; Chen, X.; Zhang, J. Cancer the 'RBP'eutics-RNA-binding proteins as therapeutic targets for cancer. Pharmacol. Ther. 2019, 203, 107390. [CrossRef]

190. Santos, R.; Ursu, O.; Gaulton, A.; Bento, A.P.; Donadi, R.S.; Bologa, C.G.; Karlsson, A.; Al-Lazikani, B.; Hersey, A.; Oprea, T.I.; et al. A comprehensive map of molecular drug targets. Nat. Rev. Drug Discov. 2017, 16, 19-34. [CrossRef]

191. Veliz, E.A.; Easterwood, L.M.; Beal, P.A. Substrate analogues for an RNA-editing adenosine deaminase: Mechanistic investigation and inhibitor design. J. Am. Chem. Soc. 2003, 125, 10867-10876. [CrossRef]

192. Bol, G.M.; Vesuna, F.; Xie, M.; Zeng, J.; Aziz, K.; Gandhi, N.; Levine, A.; Irving, A.; Korz, D.; Tantravedi, S.; et al. Targeting DDX3 with a small molecule inhibitor for lung cancer therapy. EMBO Mol. Med. 2015, 7, 648-669. [CrossRef] [PubMed]

193. Kondaskar, A.; Kondaskar, S.; Kumar, R.; Fishbein, J.C.; Muvarak, N.; Lapidus, R.G.; Sadowska, M.; Edelman, M.J.; Bol, G.M.; Vesuna, F.; et al. Novel, Broad Spectrum Anti-Cancer Agents Containing the Tricyclic 5:7:5-Fused Diimidazodiazepine Ring System. ACS Med. Chem. Lett. 2010, 2, 252-256. [CrossRef] [PubMed]

194. Xie, M.; Vesuna, F.; Tantravedi, S.; Bol, G.M.; van Voss, M.R.H.; Nugent, K.; Malek, R.; Gabrielson, K.; van Diest, P.J.; Tran, P.T.; et al. RK-33 Radiosensitizes Prostate Cancer Cells by Blocking the RNA Helicase DDX3. Cancer Res. 2016, 76, 6340-6350. [CrossRef] [PubMed]

195. Xie, M.; Vesuna, F.; Botlagunta, M.; Bol, G.M.; Irving, A.; Bergman, Y.; Hosmane, R.S.; Kato, Y.; Winnard, P.T., Jr.; Raman, V. NZ51, a ring-expanded nucleoside analog, inhibits motility and viability of breast cancer cells by targeting the RNA helicase DDX3. Oncotarget 2015, 6, 29901-29913. [CrossRef] [PubMed]

196. Yedavalli, V.S.; Zhang, N.; Cai, H.; Zhang, P.; Starost, M.F.; Hosmane, R.S.; Jeang, K.T. Ring expanded nucleoside analogues inhibit RNA helicase and intracellular human immunodeficiency virus type 1 replication. J. Med. Chem. 2008, 51, 5043-5051. [CrossRef] [PubMed]

197. Maga, G.; Falchi, F.; Radi, M.; Botta, L.; Casaluce, G.; Bernardini, M.; Irannejad, H.; Manetti, F.; Garbelli, A.; Samuele, A.; et al. Toward the discovery of novel anti-HIV drugs. Second-generation inhibitors of the cellular ATPase DDX3 with improved anti-HIV activity: Synthesis, structure-activity relationship analysis, cytotoxicity studies, and target validation. ChemMedChem 2011, 6, 1371-1389. [CrossRef] [PubMed]

198. Maga, G.; Falchi, F.; Garbelli, A.; Belfiore, A.; Witvrouw, M.; Manetti, F.; Botta, M. Pharmacophore modeling and molecular docking led to the discovery of inhibitors of human immunodeficiency virus-1 replication targeting the human cellular aspartic acid-glutamic acid-alanine-aspartic acid box polypeptide 3. J. Med. Chem. 2008, 51, 6635-6638. [CrossRef] [PubMed]

199. Radi, M.; Falchi, F.; Garbelli, A.; Samuele, A.; Bernardo, V.; Paolucci, S.; Baldanti, F.; Schenone, S.; Manetti, F.; Maga, G.; et al. Discovery of the first small molecule inhibitor of human DDX3 specifically designed to target the RNA binding site: Towards the next generation HIV-1 inhibitors. Bioorg. Med. Chem. Lett. 2012, 22, 2094-2098. [CrossRef]

200. Samal, S.K.; Routray, S.; Veeramachaneni, G.K.; Dash, R.; Botlagunta, M. Ketorolac salt is a newly discovered DDX3 inhibitor to treat oral cancer. Sci. Rep. 2015, 5, 9982. [CrossRef] 
201. Meisner, N.C.; Hintersteiner, M.; Mueller, K.; Bauer, R.; Seifert, J.M.; Naegeli, H.U.; Ottl, J.; Oberer, L.; Guenat, C.; Moss, S.; et al. Identification and mechanistic characterization of low-molecular-weight inhibitors for HuR. Nat. Chem. Biol. 2007, 3, 508-515. [CrossRef]

202. Chae, M.J.; Sung, H.Y.; Kim, E.H.; Lee, M.; Kwak, H.; Chae, C.H.; Kim, S.; Park, W.Y. Chemical inhibitors destabilize HuR binding to the AU-rich element of TNF-alpha mRNA. Exp. Mol. Med. 2009, 41, 824-831. [CrossRef] [PubMed]

203. D'Agostino, V.G.; Adami, V.; Provenzani, A. A novel high throughput biochemical assay to evaluate the HuR protein-RNA complex formation. PLoS ONE 2013, 8, e72426. [CrossRef] [PubMed]

204. D'Agostino, V.G.; Lal, P.; Mantelli, B.; Tiedje, C.; Zucal, C.; Thongon, N.; Gaestel, M.; Latorre, E.; Marinelli, L.; Seneci, P.; et al. Dihydrotanshinone-I interferes with the RNA-binding activity of HuR affecting its post-transcriptional function. Sci. Rep. 2015, 5, 16478. [CrossRef] [PubMed]

205. Wang, Z.; Bhattacharya, A.; Ivanov, D.N. Identification of Small-Molecule Inhibitors of the HuR/RNA Interaction Using a Fluorescence Polarization Screening Assay Followed by NMR Validation. PLoS ONE 2015, 10, e0138780. [CrossRef]

206. Wu, X.; Lan, L.; Wilson, D.M.; Marquez, R.T.; Tsao, W.C.; Gao, P.; Roy, A.; Turner, B.A.; McDonald, P.; Tunge, J.A.; et al. Identification and validation of novel small molecule disruptors of HuR-mRNA interaction. ACS Chem. Biol. 2015, 10, 1476-1484. [CrossRef]

207. Kaur, K.; Wu, X.; Fields, J.K.; Johnson, D.K.; Lan, L.; Pratt, M.; Somoza, A.D.; Wang, C.C.C.; Karanicolas, J.; Oakley, B.R.; et al. The fungal natural product azaphilone-9 binds to HuR and inhibits HuR-RNA interaction in vitro. PLoS ONE 2017, 12, e0175471. [CrossRef]

208. Li, M.; Zhang, L.; Ge, C.; Chen, L.; Fang, T.; Li, H.; Tian, H.; Liu, J.; Chen, T.; Jiang, G.; et al. An isocorydine derivative (d-ICD) inhibits drug resistance by downregulating IGF2BP3 expression in hepatocellular carcinoma. Oncotarget 2015, 6, 25149-25160. [CrossRef]

209. Elagib, K.E.; Lu, C.H.; Mosoyan, G.; Khalil, S.; Zasadzinska, E.; Foltz, D.R.; Balogh, P.; Gru, A.A.; Fuchs, D.A.; Rimsza, L.M.; et al. Neonatal expression of RNA-binding protein IGF2BP3 regulates the human fetal-adult megakaryocyte transition. J. Clin. Investig. 2017, 127, 2365-2377. [CrossRef]

210. Mancarella, C.; Pasello, M.; Ventura, S.; Grilli, A.; Calzolari, L.; Toracchio, L.; Lollini, P.L.; Donati, D.M.; Picci, P.; Ferrari, S.; et al. Insulin-Like Growth Factor 2 mRNA-Binding Protein 3 is a Novel Post-Transcriptional Regulator of Ewing Sarcoma Malignancy. Clin. Cancer Res. 2018, 24, 3704-3716. [CrossRef]

211. Lim, D.; Byun, W.G.; Koo, J.Y.; Park, H.; Park, S.B. Discovery of a Small-Molecule Inhibitor of Protein-MicroRNA Interaction Using Binding Assay with a Site-Specifically Labeled Lin28. J. Am. Chem. Soc. 2016, 138, 13630-13638. [CrossRef]

212. Roos, M.; Pradere, U.; Ngondo, R.P.; Behera, A.; Allegrini, S.; Civenni, G.; Zagalak, J.A.; Marchand, J.R.; Menzi, M.; Towbin, H.; et al. A Small-Molecule Inhibitor of Lin28. ACS Chem. Biol. 2016, 11, 2773-2781. [CrossRef] [PubMed]

213. Lightfoot, H.L.; Miska, E.A.; Balasubramanian, S. Identification of small molecule inhibitors of the Lin28-mediated blockage of pre-let-7g processing. Org. Biomol. Chem. 2016, 14, 10208-10216. [CrossRef] [PubMed]

214. Wang, L.; Rowe, R.G.; Jaimes, A.; Yu, C.; Nam, Y.; Pearson, D.S.; Zhang, J.; Xie, X.; Marion, W.; Heffron, G.J.; et al. Small-Molecule Inhibitors Disrupt let-7 Oligouridylation and Release the Selective Blockade of let-7 Processing by LIN28. Cell Rep. 2018, 23, 3091-3101. [CrossRef] [PubMed]

215. Byun, W.G.; Lim, D.; Park, S.B. Discovery of Small-Molecule Modulators of Protein-RNA Interactions by Fluorescence Intensity-Based Binding Assay. ChemBioChem 2020, 21, 818-824. [CrossRef] [PubMed]

216. Lorenz, D.A.; Kaur, T.; Kerk, S.A.; Gallagher, E.E.; Sandoval, J.; Garner, A.L. Expansion of cat-ELCCA for the Discovery of Small Molecule Inhibitors of the Pre-let-7-Lin28 RNA-Protein Interaction. ACS Med. Chem. Lett. 2018, 9, 517-521. [CrossRef]

217. Bedi, R.K.; Huang, D.; Eberle, S.A.; Wiedmer, L.; Sledz, P.; Caflisch, A. Small-Molecule Inhibitors of METTL3, the Major Human Epitranscriptomic Writer. ChemMedChem 2020, 15, 744-748. [CrossRef]

218. Minuesa, G.; Antczak, C.; Shum, D.; Radu, C.; Bhinder, B.; Li, Y.; Djaballah, H.; Kharas, M.G. A 1536-well fluorescence polarization assay to screen for modulators of the MUSASHI family of RNA-binding proteins. Comb. Chem. High Throughput Screen. 2014, 17, 596-609. [CrossRef] 
219. Minuesa, G.; Albanese, S.K.; Xie, W.; Kazansky, Y.; Worroll, D.; Chow, A.; Schurer, A.; Park, S.M.; Rotsides, C.Z.; Taggart, J.; et al. Small-molecule targeting of MUSASHI RNA-binding activity in acute myeloid leukemia. Nat. Commun. 2019, 10, 2691. [CrossRef]

220. Clingman, C.C.; Deveau, L.M.; Hay, S.A.; Genga, R.M.; Shandilya, S.M.; Massi, F.; Ryder, S.P. Allosteric inhibition of a stem cell RNA-binding protein by an intermediary metabolite. eLife 2014, 3, e02848. [CrossRef]

221. Lan, L.; Appelman, C.; Smith, A.R.; Yu, J.; Larsen, S.; Marquez, R.T.; Liu, H.; Wu, X.; Gao, P.; Roy, A.; et al. Natural product (-)-gossypol inhibits colon cancer cell growth by targeting RNA-binding protein Musashi-1. Mol. Oncol. 2015, 9, 1406-1420. [CrossRef]

222. Tang, J.; Huang, Z.M.; Chen, Y.Y.; Zhang, Z.H.; Liu, G.L.; Zhang, J. A novel inhibitor of human La protein with anti-HBV activity discovered by structure-based virtual screening and in vitro evaluation. PLoS ONE 2012, 7, e36363. [CrossRef] [PubMed]

223. Kumar, D.; Das, M.; Sauceda, C.; Ellies, L.G.; Kuo, K.; Parwal, P.; Kaur, M.; Jih, L.; Bandyopadhyay, G.K.; Burton, D.; et al. Degradation of splicing factor SRSF3 contributes to progressive liver disease. J. Clin. Investig. 2019, 129, 4477-4491. [CrossRef] [PubMed]

224. Crooke, S.T.; Witztum, J.L.; Bennett, C.F.; Baker, B.F. RNA-Targeted Therapeutics. Cell Metab. 2018, 27, 714-739. [CrossRef]

225. Kole, R.; Krainer, A.R.; Altman, S. RNA therapeutics: Beyond RNA interference and antisense oligonucleotides. Nat. Rev. Drug Discov. 2012, 11, 125-140. [CrossRef] [PubMed]

226. Taylor, R.D.; MacCoss, M.; Lawson, A.D. Rings in drugs. J. Med. Chem. 2014, 57, 5845-5859. [CrossRef] [PubMed]

227. Gu, L.; Zhang, H.; Liu, T.; Zhou, S.; Du, Y.; Xiong, J.; Yi, S.; Qu, C.K.; Fu, H.; Zhou, M. Discovery of Dual Inhibitors of MDM2 and XIAP for Cancer Treatment. Cancer Cell 2016, 30, 623-636. [CrossRef]

228. Wang, Y.; Lai, H.; Fan, X.; Luo, L.; Duan, F.; Jiang, Z.; Wang, Q.; Leung, E.L.H.; Liu, L.; Yao, X. Gossypol Inhibits Non-small Cell Lung Cancer Cells Proliferation by Targeting EGFR(L858R/T790M). Front. Pharmacol. 2018, 9 , 728. [CrossRef]

229. Xiong, J.; Li, J.; Yang, Q.; Wang, J.; Su, T.; Zhou, S. Gossypol has anti-cancer effects by dual-targeting MDM2 and VEGF in human breast cancer. Breast Cancer Res. 2017, 19, 27. [CrossRef]

230. Nalawansha, D.A.; Crews, C.M. PROTACs: An Emerging Therapeutic Modality in Precision Medicine. Cell Chem. Biol. 2020, 27, 998-1014. [CrossRef]

231. Huang, H.; Zeqiraj, E.; Dong, B.; Jha, B.K.; Duffy, N.M.; Orlicky, S.; Thevakumaran, N.; Talukdar, M.; Pillon, M.C.; Ceccarelli, D.F.; et al. Dimeric structure of pseudokinase RNase L bound to 2-5A reveals a basis for interferon-induced antiviral activity. Mol. Cell 2014, 53, 221-234. [CrossRef]

232. Hudson, W.H.; Ortlund, E.A. The structure, function and evolution of proteins that bind DNA and RNA. Nat. Rev. Mol. Cell Biol. 2014, 15, 749-760. [CrossRef] [PubMed]

233. Moududee, S.A.; Jiang, Y.; Gilbert, N.; Xie, G.; Xu, Z.; Wu, J.; Gong, Q.; Tang, Y.; Shi, Y. Structural and functional characterization of hMEX-3C Ring finger domain as an E3 ubiquitin ligase. Protein Sci. 2018, 27, 1661-1669. [CrossRef] [PubMed]

234. Popow, J.; Alleaume, A.M.; Curk, T.; Schwarzl, T.; Sauer, S.; Hentze, M.W. FASTKD2 is an RNA-binding protein required for mitochondrial RNA processing and translation. RNA 2015, 21, 1873-1884. [CrossRef] [PubMed]

235. Caudron-Herger, M.; Rusin, S.F.; Adamo, M.E.; Seiler, J.; Schmid, V.K.; Barreau, E.; Kettenbach, A.N.; Diederichs, S. R-DeeP: Proteome-wide and Quantitative Identification of RNA-Dependent Proteins by Density Gradient Ultracentrifugation. Mol. Cell 2019, 75, 184-199. [CrossRef] [PubMed]

236. Scott, D.E.; Bayly, A.R.; Abell, C.; Skidmore, J. Small molecules, big targets: Drug discovery faces the protein-protein interaction challenge. Nat. Rev. Drug Discov. 2016, 15, 533-550. [CrossRef]

237. Boettcher, M.; Lawson, A.; Ladenburger, V.; Fredebohm, J.; Wolf, J.; Hoheisel, J.D.; Frezza, C.; Shlomi, T. High throughput synthetic lethality screen reveals a tumorigenic role of adenylate cyclase in fumarate hydratase-deficient cancer cells. BMC Genom. 2014, 15, 158. [CrossRef]

238. Boettcher, M.; Tian, R.; Blau, J.A.; Markegard, E.; Wagner, R.T.; Wu, D.; Mo, X.; Biton, A.; Zaitlen, N.; $\mathrm{Fu}, \mathrm{H}$.; et al. Dual gene activation and knockout screen reveals directional dependencies in genetic networks. Nat. Biotechnol. 2018, 36, 170-178. [CrossRef] 
239. Colic, M.; Wang, G.; Zimmermann, M.; Mascall, K.; McLaughlin, M.; Bertolet, L.; Lenoir, W.F.; Moffat, J.; Angers, S.; Durocher, D.; et al. Identifying chemogenetic interactions from CRISPR screens with drugZ. Genome Med. 2019, 11, 52. [CrossRef]

240. Zhan, T.; Boutros, M. Towards a compendium of essential genes-From model organisms to synthetic lethality in cancer cells. Crit. Rev. Biochem. Mol. Biol. 2016, 51, 74-85. [CrossRef] 